\title{
Searching for long-range dependence in real effective exchange rate: towards parity?
}

\author{
André M. Marques \\ Professor - Universidade Federal da Paraíba (UFPB) \\ Endereço: Campus I - Cidade Universitária, s/n, João Pessoa - Paraíba/PB - Brasil \\ CEP: 58051-900 - E-mail: 00094751@ufrgs.br
}

\section{Fábio Pesavento}

Coordenador do Núcleo de Economia Empresarial - (ESPM-Sul)

Endereço: Rua Guilherme Schell, 350 - Bairro Santo Antônio - Porto Alegre/RS - Brasil

CEP: 90640-040 - E-mail: fpesavento@espm.br

Recebido em 24 de abril de 2014. Aceito em 17 de outubro de 2014.

\begin{abstract}
After the widespread adoption of flexible exchange rate regime since 1973 the volatility of the exchange rate has increased, as a consequence of greater trade openness and financial integration. As a result, it has become difficult to find evidence of the purchasing power parity hypothesis (PPP). This study investigates the possibility of a fall in the persistence of the real exchange rate as a consequence of the financial and commercial integration by employing monthly real effective exchange rate dataset provided by the International Monetary Fund (IMF). Beginning with an exploratory data analysis in the frequency domain, the fractional coefficient $d$ was estimated employing the biasreduced estimator on a sample of 20 countries over the period ranging from 1975 to 2011 . As the main novelty, this study applies a bias-reduced log-periodogram regression estimator instead of the traditional method proposed by GPH which eliminates the first and higher orders biases by a data-dependent plug-in method for selecting the number of frequencies to minimize asymptotic mean-squared error (MSE). Additionally, this study also estimates a moving window of fifteen years to observe the path of the fractional coefficient in each country. No evidence was found of a statistically significant change in the persistence of the real exchange rate.
\end{abstract}

\section{Keywords}

Purchasing power parity. Persistence. Fractional integration. Real exchange rate.

\section{Resumo}

Após a adoção generalizada do regime de câmbio flexível nos diversos países desde 1973 , a volatilidade da taxa cambial aumentou, em contexto de maior abertura comercial e integração financeira. Tornou-se mais difícil encontrar evidências favoráveis

- Both authors are immensely grateful to Prof. Vinicius Aguiar de Souza for the many comments, suggestions and detailed discussions in a previous draft. Both authors are grateful to Prof. Edilean Kleber da Silva Bejarano Aragón for their suggestions on earlier version of the work. The first author gratefully acknowledges financial support from CNPq (Process 475415/2013-2) and the efficient assistance of Prof. Fábio Pesavento in various stages of research. Any remaining errors are of entire responsibility of the authors. This paper was presented at XXXIX Simposio de la Asociación Española Economía which occurred in Palma de Mallorca, Spain, on 11 - 13 December 2014. The first author is also grateful for financial assistance of CAPES (AEX 7824/14-9). 
à hipótese da paridade do poder de compra. Este estudo analisa a possibilidade de queda na persistência da taxa de câmbio real como consequência da abertura comercial e integração financeira, com dados mensais de 20 países no período de 1975 a 2011. A partir de uma análise exploratória dos dados no domínio da frequência, o coeficiente fracionário $d$ foi obtido utilizando-se um estimador semiparamétrico com redução de viés em que um algoritmo dependente dos dados seleciona o número ótimo de frequências que minimiza o erro quadrático médio, diferente do estimador tradicional GPH. O estudo também utiliza uma janela móvel de 15 anos para identificar a evolução do coeficiente fracionário ao longo dos anos. Não há evidência de queda na persistência da taxa de câmbio real, nem indicações que corroborem a hipótese da paridade do poder de compra.

\section{Palavras-Chave}

Paridade do poder de compra. Persistência. Integração fracionária. Taxa de câmbio real.

\section{Classificação JEL}

F31. F41.

\section{Introduction}

One of the most controversial hypotheses in macroeconomics is the assertion that a homogeneous commodity sold in different countries must have the same selling price, in the different currencies, after the conversion by the exchange rate. Once taken the conversion, the differences observed in prices would be eliminated by arbitrage operations. In the aggregate, for all the different commodities and services, the corollary of the single price law is that the real exchange rate should converge to a constant in the long run, resulting in the hypothesis of purchasing power parity (PPP), which implies the stationarity of the real exchange rate. Although analyzing its relative version is of great importance, this work examines only its absolute version. ${ }^{1}$

The importance of this theoretical assumption is widely recognized in macroeconomics (Obstfeld and Rogoff, 1996: Chapter 4) with many known examples of its applications: choice of initial rates for a newly independent country, to forecast medium and long run for the real exchange rate, to make international comparisons of income, since wages and prices are quoted in different units of measure. ${ }^{2}$

1 For a detailed exposition of the relative version of PPP hypothesis, see Sarno and Taylor (2002) and specially Rogoff (1996).

2 The description of the main historical example of an application of PPP hypothesis can be found in Rogoff (1996, p. 648-9) and Franco (1998, p. 132-4). This historical example refers to the problem of how to restore world financial system after its collapse during World War 
Regarding the study by Okimoto and Shimotsu (2010) which adopt a fractional approach to the issue, this study seeks to advance the following aspects: (1) selection of the most appropriate database to measure the long run persistence of exchange rate taking into account the weight of trade, (2) increased the data points and the number of countries, (3) use of a more efficient semiparametric estimator with reduced bias, (4) estimation of a fifteen-year moving window, showing the path of persistence since 1980, along with the study by Okimoto and Shimotsu (2010) for comparison purposes only. With these additions and modifications news results were found, similar to the ones found in the studies of Engel (2000) and Taylor and Taylor (2004).

In summary, the aim of this study is to investigate the hypothesis of purchasing power parity in a fractional perspective through the semiparametric estimator introduced by Andrews and Guggenberger (2003) (AGG) with reduced bias, in order to test the hypothesis of change in the persistence of the real effective exchange rate before and after the economic opening and financial liberalization of the 1990s. The use of a more appropriate basis for measuring competitiveness with more data points can provide more reliable evidence on the stationarity nature of the real exchange rate of the countries.

The central hypothesis suggested by Shimotsu and Okimoto (2010) is that the coefficient of persistence may have been reduced in most countries after the financial and trade integration since the 1990s by the action of the stabilizing factors mentioned below, which may have made the real exchange rate stationary towards purchasing power parity hypothesis. However, taking into account the weight of trade between economies, more countries and longer samples, the results do not corroborate the findings of previous studies and support the conclusions of Engel (2000) and Rogoff (1996).

I. When the War ended, the problem was how to reset the level of nominal exchange rates between countries. Gustav Cassel was probably the first economist in proposing a practical application of this theory to setting parities between exchange rates in that time. Today, the Big Mac index published regularly by the The Economist is the more trivial example to unfold whether a nominal exchange rate is over or undervalued in relation to its theoretical value (see Taylor and Taylor, 2004; Rogoff, 1996). Since the theory presupposes which commodities produced internationally are perfect substitutes to define the ratio between their prices as the theoretical value for exchange rate, Rogoff (1996, p. 650) points out that for highly traded commodities like gold, "the law of one price hold very well" but some reservations are needed when we apply the Big Mac index because the costs to produce it can vary between countries. 
For most of the countries in the sample there was an increase in the long run persistence of the real exchange rate. The null hypothesis of equal persistence before and after the institutional changes of the 1990s cannot be rejected at conventional levels of probability. We conclude that there is no statistically significant change in the persistence of the real exchange rate before and after the opening of trade and financial integration among economies. On the contrary, in many countries there is a positive trend in the persistence measure documented by the moving window of fifteen years.

The PPP hypothesis has been studied, in most cases, with the application of a wide variety of unit root tests. In these studies, it is observed that the specification of the model used, the time window and the database also vary. The rejection of the unit root hypothesis is interpreted as evidence in favor of PPP. In this perspective, with the data for the real exchange rate in a sample of twenty countries, Taylor (2002: 144) reports evidence favorable to the hypothesis of purchasing power parity. Divino et al. (2009) and Kim and Lima (2010) are other examples of recent studies using the approach of the unit root test in order to verify the PPP hypothesis.

Although some studies have found evidence favorable to this theoretical assumption, Taylor and Taylor (2004: 143) conclude: "The flurry of empirical studies employing these types of tests (...) among major industrialized countries that emerged (...) were unanimous in their failure to reject the unit root hypothesis for major real exchange rates - this was probably due to the low power of the tests".

The low power of the unit root tests (especially ADF and PP) persisted in the literature, despite the fact that a variety of authors increased the sample size through simulations or added more observations over time and also more countries in the database (Lothian and Taylor, 1997; Sarno and Taylor, 2002). Indeed, the addition of data for longer historical periods gave rise to the question of how to interpret these results, since they included so different exchange rate regimes or different historical periods from several decades (before 1973, for example).

Results of more recent studies reinforce the controversy surrounding this assumption. Engel (2000), for example, suggests that the huge price dispersion across countries must be understood from the 
nonstationary behavior of the exchange rate, consistent with the Balassa-Samuelson effect, by which developed countries have price levels significantly higher than developing countries because of the productive structure and the high share of services in the aggregate product, which complicates the equalization of prices internationally postulated by purchasing power parity. In general, the results presented by Engel (2000) did not corroborate the PPP hypothesis. Similarly, Rogoff (1996) notes substantial price dispersion across countries, analyzing the data base by Summers and Heston (1991).

Besides the low power of unit root tests previously pointed out (Taylor and Taylor, 2004), another limitation of this approach is to investigate only the extreme cases, in which the process $\left\{X_{t}\right\}$ is considered integrated of order $d$, denoted by $X_{t} \sim I(d)$, where $d$ can only assume the values zero or one: the series would have infinite persistence or no persistence. Because of these two limitations, in the same direction of the study by Okimoto and Shimotsu (2010), this study proposes the adoption of a fractional approach to find evidence on the hypothesis of purchasing power parity for a sample of twenty countries with monthly data from January 1975 to November 2011 provided by the International Monetary Fund (IMF, 2012).

The fractional approach provides a more flexible alternative to the above mentioned extreme cases, since the fractional coefficient $d$ can assume any real value in the interval $(-0.5 ; 1)$. The fractional approach has been used to measure the long-range dependence (or long memory) in macroeconomic variables such as inflation, exchange rates, interest rates, unemployment, etc. In the Brazilian literature, Figueiredo and Marques (2009), after detecting evidence of long memory in two subsamples of the Brazilian inflation, fail to reject the hypothesis of inertial inflation and its persistence to inflationary or deflationary shocks using the fractional coefficient $d$ for the first and second moments of the process. Into two subsamples, the authors find evidence of long memory. The authors conclude that in the post-Real Plan persistence was significantly reduced and the process became reversible in average, which contrasts with previous periods. In the same direction, Silva and Vieira (2013) analyzed the behavior of inflation in the metropolitan regions of Brazil and their results, in general, corroborate the results by Figueiredo and Marques (2009). 
Considering the international context, studies which measure the persistence of macroeconomic series suggest that it may have been significantly reduced after trade liberalization and the deepening of financial integration among economies. In particular, some authors argue that greater economic openness and capital account liberalization would reduce the volatility of the output by favoring consumption smoothing, with beneficial effects on the growth of countries (Kose et al., 2006). This wave of expansion of global finance and trade interdependence has gradually expanded in industrialized countries during the 1970s and 1980s on the grounds of combating "financial repression", and it expanded rapidly from the 1990s up to the present time (Lane and Milesi-Ferretti, 2006; Kose et al., 2006).

Concurrently with the institutional changes mentioned, the early 1980s and 1990s also witnessed a spectacular expansion of participation of the Asian capital markets in the global capital markets. Indeed, Arshanapalli et al. (1995) documented a substantial increase in the interdependence between the capital markets of the United States, Japan, Hong Kong, Malaysia, Philippines, Singapore and Thailand after the 1987 crash. Additionally, Sensier and van Dijk (2004) found a decline of volatility in various economic series (employment, consumption, wages and prices) in the United States from the mid-1980s, which may be contributing to the stabilization of the other economies, through greater interdependence. Still under this perspective, Ahmed et al. (2004) reported a substantial decline in U.S. output volatility in the period from 1984 to 2002 in the components of aggregate demand and consumer prices compared with the pre-1984 period, contributing to the stabilization of other economies. According to the authors, "the decline in output variability appears to be mirrored in all major demand-side and product-side components of GDP, as well as in the inflation rate and many other macroeconomic and financial variables" (Ahmed et al., 2004, p. 824).

Studying the behavior of inflation in many economies, Kumar and Okimoto (2007) found a notable decline in inflation persistence since the 1980s in the U.S. and in the G7 countries measured by fractional coefficient, except Italy. However, there is no consensus in the literature that analyzes the persistence of inflation. Pivetta and Reis (2007) using a variety of measures of short run persistence with a quarterly database (1947: II to 2001: III) find no evidence of a fall in inflation persistence in the United States. 
Despite the contribution of the above mentioned factors to the stabilization of the economies in general, the real exchange rate may have preserved its nonstationary character due to the substantial increase in volatility during the period of floating exchange rates (since 1973), with negative impacts on production and trade of various economies (Rajan, et al. 2002). On this point, Rogoff (1996, p. 647) notes that, for the period of one month, the volatility of the real exchange rate is roughly the same volatility of the nominal exchange rate. According to Rogoff, "Price differential volatility is surprisingly large even when one confines attention to relatively homogenous classes of highly traded goods".

Eichengreen et al. (1996) documented the contagion effect of various speculative attacks on the exchange rate in a sample of twenty industrial countries in the period between 1959 and 1993. The largest commercial and financial integration among the economies may have contributed to strengthening the volatile nature of the exchange rate. The authors conclude that currency crises increased by 0.08 the probability of speculative attacks, with adverse effects on the competition and trade in the country, regardless of macroeconomic fundamentals.

Having this set of factors that contribute to stabilizing the economies and its possible impact on other countries with stronger trade and financial transactions, the question is whether these stabilizing influences are also being transmitted to the level of competitiveness of the countries in general, offsetting the increased volatility of the nominal exchange rate and its adverse effects on trade and production, supporting the hypothesis of purchasing power parity. The institutional changes implemented in several countries in the 1990s, such as the economic openness and greater financial integration, could have become the real stationary exchange rate, contributing to the fall in their persistence to shocks.

Taking into account the results of the above mentioned studies, the present paper, in addition to measuring the persistence in order to test the hypothesis of purchasing power parity, also tests the hypothesis of change in persistence with some modest modifications in relation to Okimoto and Shimotsu (2010). That is, the null hypothesis of maintaining persistence $\left(d_{1}=d_{2}\right)$ was formally tested against the alternative hypothesis of a fall in the persistence of real exchange rate $\left(d_{1}>d_{2}\right)$, initially suggested by Shimotsu and Okimoto (2010). 
The paper is organized as follows. After the Introduction, section two describes the database and presents the methodology used in the study. Section three presents and discusses the results and in section four, the final comments are made.

\section{Methodology}

The steps adopted in this study were four. Initially, we seek evidence of fractional behavior with exploratory data analysis in the frequency domain, following the approach by Beran (1994), by exploring scatter plots between frequency and periodogram, both in logarithmic scale. Next, following the study by Baillie et al. (1996), two complementary tests for stationarity/nonstationarity were combined in order to obtain evidence of fractional behavior, in which the rejection of the null hypothesis of both tests suggests that the series is neither I (1) nor I (0), but fractionally integrated. The basic change in relation to the study by Baillie et al. (1996) is to apply a more efficient test for time series with higher persistence introduced by Elliott et al. (1996). A step further was made by applying the unit root test introduced by Lee and Strazicich (2003) which considers the possibility of (two) occasional changes on level of the series.

Subsequently, we proceeded with the estimation of the fractional coefficient for full and partitioned samples before and after the intensification of financial integration. Finally, a moving window of fifteen years was estimated in order to observe the path of the long run persistence over time, to the extent that the economies became more financially and commercially integrated. The evolution of the fractional coefficient is shown in the Appendix, in which the horizontal line is attached to the unit $(d=1)$, suggesting that the persistence of the real exchange rate remains above the unit in most countries in the sample.

\subsection{The dataset}

The study by Okimoto and Shimotsu (2010) uses a sample of 17 countries in the period of 1974:01 to 2006:12. The sample dataset in 
this work covers the period from 1975:01 to 2011:11, generating an increase of about 5 years of data points with three added countries. The selection of the database to be used in the study takes into account the availability of monthly series for the post-1973 period in the database of the International Monetary Fund (IMF, 2012). ${ }^{3}$

Now, we search for a measure of the exchange rate that may more accurately reflect the competitiveness between countries. Overall, most studies employ the real exchange rate without taking into account the weight of trade between countries. This choice of data has been criticized in the literature because the trade balance, through the availability of foreign money, tends to influence the level of the exchange rate.

There are well documented evidences that the trade balance strongly influences the behavior of the real exchange rate (Helmers, 1991; Joyce and Kamas, 2003; Okimoto and Shimotsu, 2010). Therefore, Cline and Williamson (2011: p. 2) note that "the relevant exchange rate concept is an effective rate, i.e., one which in foreign currencies are taken into account and weighted by their importance in the foreign trade of the country in question to form a single estimate of the exchange rate". According to Cline and Williamson (2011), "The practice of measuring a currency's value in terms of the currency of single trading partner and calling this 'the exchange rate' is quite wrong for any country with reasonably diversified trade". For these reasons, the variable used in the study was the real effective exchange rate based on consumer price index for each individual country, extracted from the CD-Rom of the International Monetary Fund (IMF, 2012).

Nevertheless, since for some specific countries and periods there were no observations available, the Table 1 below presents in details the country and also the period in which data were available, with the respective sample size $(n)$ for the estimations. The choice of the time period can be justified historically. Indeed, like Taylor and Taylor (2004: 141) observes: "in 1971, President Nixon ended the convertibility of the U.S. dollar relative to gold. After failed

\footnotetext{
3 The complete sample of countries at IMF's CD-ROM was thirty. However, for Canada, Cyprus, Germany, Greece, Ireland, Italy, Netherlands, Portugal, Slovak Republic, and Japan there are missing data in some periods of the sample. For Canada, for example, there are missing data in following periods: 2003:10; 2004:04; 2004:06 and 2004:09. The complete dataset can be send to the reader on request.
} 
attempts to restore a version of the Bretton Woods agreement, the major currencies of the world began floating against each other in March 1973".

For some countries, data were available before 1975, however, this year was chosen as the initial period because it reflects the historical widespread adoption of generalized floating exchange rate regime for the sample countries.

Table 1 - Sample of countries - several periods

\begin{tabular}{l|c|l|c}
\hline \hline \multicolumn{1}{c|}{ Country/Period } & $n$ & \multicolumn{1}{c|}{ Country/Period } & $n$ \\
\hline 1. Austria/1975:01-2011:11 & 443 & 11. Spain/1980:01-2011:11 & 383 \\
\hline 2. Belgium/1975:01-2011:11 & 443 & 12. Brazil/1979:12-2011:11 & 384 \\
\hline 3. Finland/1975:01-2011:11 & 443 & 13. Chile/1979:12-2011:11 & 384 \\
\hline 4. France/1979:12-2011:11 & 384 & 14. Israel/1975:01-2011:11 & 443 \\
\hline 5. Malaysia/1975:01-2011:11 & 443 & 15. Mexico/1979:12-2011:11 & 384 \\
\hline 6. Denmark/1975:01-2011:11 & 443 & 16. Switzerland/1975:01-2011:11 & 443 \\
\hline 7. Sweden/1975:01-2011:11 & 443 & 17. Norway/1975:01-2011:11 & 443 \\
\hline 8. New Zealand/1975:02-2011:11 & 442 & 18. United States/1979:12-2011:11 & 384 \\
\hline 9. Luxembourg/1975:02-2011:11 & 442 & 19. United Kingdom/1975:02-2011:11 & 442 \\
\hline 10. China/1979:12-2011:11 & 384 & 20. Hungary/1979:12-2011:11 & 384 \\
\hline \hline
\end{tabular}

Source: Authors' elaboration based on data extracted from the CD-Rom of IMF (2012).

\subsection{Exploratory data analysis: periodogram and frequency}

The long memory coefficient $d$ measures the persistence of a variable in the long run and it is generally identified from the slow hyperbolic decay of the autocorrelations at high lags of a time series. In the frequency domain, however, the analysis of the periodogram along with the frequencies can suggest the slow (hyperbolic) decay of autocorrelations. In this case, the long-range dependence is suggested from the occurrence of inverse correlation (on a logarithmic scale) between frequency and periodogram, in which the absence of long memory is identified by random scattering around a constant situated near the origin of the periodogram.

Evidence for an inverse correlation is the typical behavior of a stationary process in which the autocorrelations are not summable, featuring long-range dependence (Beran, 1994). Figures la, lb, and lc of the Appendix describe the behavior of the correlation structure of the real exchange rate. In particular, the scatter diagram 
was constructed from the ordered pairs of periodogram $I_{j}(\cdot)$ and frequencies $\left(\lambda_{j}\right)$ defined in the expression (5) below.

\subsection{Semiparametric estimator by Andrews-Guggenberger (2003) (AGG)}

Since the contribution by Robinson (1995) the semiparametric estimation of fractional coefficient $d$ has been an active area of research. In the frequency domain, two approaches have been intensively studied in the literature: the regression of the logarithm of the periodogram (GPH, Geweke and Porter-Hudak, 1983) and the local Whittle estimator (LW, Künsch, 1987). The GPH estimator has been widely criticized for its strong bias in finite samples (Agiakloglou, Wohar and Newbold, 1993).

More recently, Andrews and Guggenberger (2003) introduced a new estimator with similar properties to the traditional GPH, but with two very desirable features: with elimination of bias for small and large samples and higher speed of convergence to zero of the mean -squared error (MSE) relative to the GPH and Whittle estimators. Indeed, this study applies a bias-reduced log-periodogram regression estimator instead of the traditional method proposed by Geweke and Porter-Hudak (1983) (GPH). The main advantage of this alternative method is to eliminate the first and higher orders biases of the GPH estimator. It employs assumptions on the spectrum only in the zero frequency neighborhood with a data-dependent plug-in method for selecting the number of frequencies in order to minimize asymptotic mean-squared error (MSE).

Okimoto and Shimotsu (2010) employ a variation of the local Whittle estimator, which does not require the use of pre-filter (differentiation) in series in order to estimate fractional coefficient. There are still no comparative studies measuring the efficiency of these estimators.

Consider $d \in\left(-\frac{1}{2}, \frac{1}{2}\right)$ the order of integration of a fractional process. The process $X_{t}$ integrated of order $d$ is defined by:

$$
(1-B)^{d}\left(X_{t}-\mu\right)=u_{t}, \quad t \in \mathbf{Z}
$$


where $\mu$ is the mean, $B$ is the lag operator and $\left\{u_{t}\right\}_{t \in \mathbf{Z}}$ has zero mean and constant variance. Where,

$$
(1-B)^{d}=\left\{1-d B+\frac{d(d-1) B^{2}}{2 !}-\frac{d(d-1)(d-2) B^{3}}{3 !}+\ldots\right\}=\sum_{p=0}^{\infty} \frac{\Gamma(p-d) B^{p}}{\Gamma(-d) \Gamma(p+1)}
$$

in which $\Gamma(\cdot)$ is the gamma function. It is said that the process $X_{t}$ has long memory if $d \in\left(0, \frac{1}{2}\right)$, short memory if $d=0$, and it is considered antipersistent if $d \in\left(-\frac{1}{2}, 0\right)$, it will be a long memory process (nonstationary), with infinite variance, but reversible to the average if $d \in\left(\frac{1}{2}, 1\right)$. In the case of $d$ greater than the unit, the process exhibits infinite persistence and is nonstationary.

The semiparametric estimator proposed by Andrews-Guggenberger (2003) is the same one introduced by GPH, except for the inclusion of frequencies in the power $2 k$, for $k=1,2, \ldots, r$ for some positive integer $r$ as additional covariates of pseudoregression introduced by the GPH.

Consider the semiparametric model for the stationary Gaussian process $X_{t}: t=1,2, \ldots, n$. The spectral density for the series is given by

$$
f(\lambda)=|\lambda|^{-2 d} g(\lambda)
$$

where $d$ is the coefficient of long memory, in which $g(\cdot)$ is an even function which is continuous at zero with $0<g(0)<\infty$. GPH proposed a reparametrization of equation (3), wherein:

$$
f(\lambda)=|1-\exp (-i \lambda)|^{-2 d} f^{*}(\lambda)
$$

in which $f^{*}(\cdot)$ satisfies the same conditions of $g(\cdot)$, and for the first ordered $m$ frequencies of the periodogram $I_{j}$, defined by:

$$
I\left(\lambda_{j}\right)=\frac{1}{2 \pi n}\left|\sum_{t=1}^{n} X_{t} \exp \left(i t \lambda_{j}\right)\right|^{2}, \quad j=1,2, \ldots, m .
$$


Where $\lambda_{j}=\frac{2 \pi j}{n}, m$ is a positive integer lower than $n$. The GPH estimator is given by $-\frac{1}{2}$ multiplied by the least squares estimator of the slope coefficient in a regression of $\left\{\log I_{j}: j=1, \ldots, m\right\}$ on a constant and the regressor variable $\tilde{X}_{t}=\log \left|1-\exp \left(-i \lambda_{j}\right)\right|$. The GPH fractional coefficient is defined by,

$$
\hat{d}_{G P H}=\frac{-0.5 \sum_{i=1}^{m}\left(\tilde{X}_{j}-\overline{\tilde{X}}\right) \log I_{j}}{\sum_{i=1}^{m}\left(\tilde{X}_{j}-\overline{\tilde{X}}\right)^{2}}
$$

where $\overline{\tilde{X}}=\left(\frac{1}{m}\right) \sum_{i=1}^{m} \tilde{X}_{j}$. According to the specification by Robinson (1995), AGG leave the term -0.5 of the equation (6) and $\tilde{X}_{j}$ is substituted by $X_{j}=-2 \log \lambda_{j}$. And in the periodogram pseudoregression $\lambda_{j}^{2}, \lambda_{j}^{4}, \ldots, \lambda_{j}^{2 r}$ covariates are added, resulting in $d_{r}$ with reduced estimator bias for small and large samples with significantly better performance than the GPH estimator. In practice, the authors suggest lower values for $r(r=1,2)$. In case of $r=0, d_{r}$ is asymptotically equivalent to traditional $d_{G P H}$. Throughout this study it is assumed that $r=1$, given the lower standard error of the estimated coefficients.

The importance of choosing the AGG estimator is justified by the following reasons. First, in the simulations to measure the efficiency and bias of the estimator, AGG estimator showed better performance compared with other semiparametric estimators (Whittle and $\mathrm{GPH})$. Second, an integrated process of order $d$, with $d \in(-0.5,1)$, can accommodate the slow hyperbolic decay of both autocorrelations and impulse response functions that are inconsistent with $I(1)$ or $I(0)$. The long run dynamics of this process is governed solely by fractional coefficient $d$, which is a measure of persistence to shocks.

Third, as shown by Hosking (1981) and Kumar and Okimoto (2007), the estimated fractional coefficient $d$ as a measure of long run persistence does not require a specific formulation about short run dynamics to obtain the order of integration, $d$ (autoregressive - AR and 
moving average - MA coefficients). ${ }^{4}$ In other words, no assumptions are made about the exact structure of the data generating process in the short run. Indeed, these authors show that it is possible to reach quite diverging conclusions by measuring short run persistence with measures based on autoregressive coefficient (like largest autoregressive root - LARR and the sum of autoregressive coefficients - SARC measures) and the long run persistence with fractional coefficient $d$, since these two different approaches render different information and determine different behaviors of the impulse response function of the series. ${ }^{5}$

Additionally, in a semiparametric approach, the estimation of AR and MA components can impose important constraints on the fractional coefficient in small samples. About this, Sowell notes that: "The result is that the fit of the long-run behavior of the series may be sacrificed to obtain a better fit of the short-run behavior" (Sowell, 1992, p. 279).

\subsection{Partitioning of the sample}

Initially, we analyzed the literature which discusses the financial integration and economic liberalization aimed at detecting a time change considered reasonable to separate the sample into two parts. The hypothesis is that the acceleration of financial and commercial integration changed the long run persistence of real exchange rate. According with Lane and Milesi-Ferreti (2003, p. 86; 2006, p. 15), the scale of international financial integration can be measured by

$$
I F I G D P_{i t}=\frac{\left(F A_{i t}+F L_{i t}\right)}{G D P_{i t}}
$$

where $I F I G D P_{i t}$ is the calculated measure of financial integration for country $i$ at time $t, F A_{i t}\left(F L_{i t}\right)$ denotes the stock of external assets (liabilities) and $G D P_{i t}$ is the per capita Gross Domestic Product. This de facto measure of financial integration was calculated for 71 countries including developed and developing economies for the

4 For a detailed approach of LARR and SARC measures of short run persistence, see Pivetta and Reis (2007).

5 See Kumar and Okimoto (2007, p. 1473) and Hosking (1981, p. 170) for details on this aspect. 
period from 1970 to 2004 by those authors. By analyzing the path of this measure we can conclude that its acceleration take place around 1990-5 in developed and developing economies (see Lane and Milesi-Ferreti, 2006, p. 65, Figure 3).

In this study, there was no attempt to identify the exact date that would indicate a structural change in the path of index of financial integration between economies measured by (7), or whether these changes are abrupt or smooth. An additional study would be necessary to answer that question. Therefore, the hypothesis testing performed in this study can be considered conservative because it is statistically significant only if the change in the fractional coefficient is substantially big. This results interpretation is complemented by the very useful estimation of the fractional coefficient from a moving window of fifteen years for the sample of 20 countries. With this procedure we can visualize the history of the long run persistence in each country individually and the effects of theses institutional reforms on it along the decades. This procedure can offer valuable information about the stability of coefficient $d$ along the years and has been used in a number of representative works on time series (see references in Banerjee et al., 1992; Kumar and Okimoto, 2007).

As noted before, the measure of financial integration presented by Lane and Milesi-Ferretti (2006) provides strong evidence that the acceleration of financial integration took place in the mid-1990s, ${ }^{6}$ and then the sample was divided into two periods: 1975-1994 and 1995-2011. Additionally, Santos-Paulino (2002, Tab.1) also suggest, on average, the same year to the trade openness of most countries of the sample. This criterion to partition of sample is absent in the study by Okimoto and Shimotsu (2010), then we expect that our results to be more correlated with institutional changes bypassed by these countries.

Also in relation to those authors, in this paper the absence of a test to indicate the presence of long memory in the series was overcome by carrying out tests of hypotheses for the combined stationarity/ nonstationarity, complemented by descriptive analysis in frequency domain. In general, it is trivial to use only the estimation of the autocorrelation function at high lags as evidence of long memory and the significance test of the fractional coefficient (see Kumar and Okimoto, 2007; Figueiredo and Marques, 2009).

6 See also Lane e Milesi-Ferretti (2003, Figure 1, p. 25). 
Following an examination of the literature and the separation of the sample into two parts based on the study mentioned above, we proceeded with the estimation of the fractional coefficient $d$ for each period separately. The evolution of the fractional coefficient, subject to major economic events such as the financial crises of the 1990s, may have changed the data distribution, as well as the mean and variance of the process. So, the study wants to compare two populations without assuming that their distributions are normal and homoscedastic. For this end, nonparametric Wilcoxon test for related samples was applied.

Once estimated the fractional coefficient for each historical subperiod, the hypothesis to be tested is the equality of the persistence of the two periods $\left(d_{1}=d_{2}\right)$ against the alternative hypothesis of a fall in the persistence of real exchange rate $\left(d_{1}>d_{2}\right)$ due to the reasons explained in the Introduction.

\section{Results and discussion}

In this section, the results are reported for the four stages of the study: exploratory data analysis using the periodogram and frequency of the real effective exchange rate data; tests for stationarity/ nonstationarity with different null hypotheses; estimation of persistence for the full sample and partitioned one; testing for change in persistence; analysis of the temporal evolution of the measure of persistence to a 15 -year moving window.

\subsection{Evidence of fractional integration}

With regard to the scatter diagram with ordered pairs of periodogram and frequency of the series, figures $l a, l b$, and $l c$ in the Appendix illustrates the inverse correlation theoretically postulated by Beran (1994), in almost all cases, strongly suggesting the presence of long memory in the series in which the autocorrelations are not summable. By analyzing those figures we can conclude that in all cases, if we plot the autocorrelations in high lags, it would appear a hyperbolic decay characterizing presence of long memory behavior, since the pattern shown in those figures by periodogram and frequency exhibits an inverse correlation, not a random scattering about 
the origin. The further procedure for detecting signs of long memory is the same one adopted by Baillie et al. (1996), which consisted of using two joint tests to verify that the data were not consistent with a process I (1) neither with process I (0). The basic idea is that the rejection of both null hypotheses of the tests (KPSS-test and $\mathrm{P}_{\mathrm{T}}$-test) provides evidence of fractional behavior. As reported by Taylor and Taylor (2004), the traditional ADF and PP tests have low power against alternatives of high persistence. For this reason, the Phillips and Perron (1988) test, used in conjunction with the KPSS test by Baillie et al. (1996), was replaced by the $P_{T}$-test, which null hypothesis is a unit root. This test is considered efficient for high persistent series and showed better performance in the simulations by Elliot et al. (1996) compared with ADF and PP tests. The KPSS test has stationarity as the null hypothesis. The results of both tests are shown in table 2 below. The results shown in Table 2 are consistent with the information gathered in the scatter plot shown in the Appendix, in which the autocorrelations are not summable.

Table 2 - Testing for the order of integration of the real effective exchange rate - results

\begin{tabular}{l|c|l|l|l|l}
\hline \hline & \multicolumn{3}{|c|}{ KPSS } & \multicolumn{2}{c}{$H_{0}: Q_{t}^{i} \approx I(1), i=1, \ldots, 20}$. \\
\hline \multicolumn{1}{c|}{ Países } & $N$ & \multicolumn{1}{c|}{ Constant } & $\begin{array}{c}\text { Constant and } \\
\text { trend }\end{array}$ & \multicolumn{1}{c}{ Constant } & \multicolumn{1}{c}{$\begin{array}{c}\text { Constant and } \\
\text { trend }\end{array}$} \\
\hline 1. Austria & 443 & $1.2377^{\mathrm{a}}$ & $0.3634^{\mathrm{a}}$ & $21.2305^{\mathrm{a}}$ & $12.9599^{\mathrm{a}}$ \\
\hline 2. Belgium & 443 & $0.3937^{\mathrm{c}}$ & $0.1441^{\mathrm{c}}$ & $2.3095^{\mathrm{a}}$ & $8.1368^{\mathrm{a}}$ \\
\hline 3. Finland & 443 & $1.2060^{\mathrm{a}}$ & $0.2420^{\mathrm{a}}$ & $5.6137^{\mathrm{a}}$ & $16.9813^{\mathrm{a}}$ \\
\hline 4. France & 384 & $0.9162^{\mathrm{a}}$ & 0.1098 & $27.7183^{\mathrm{a}}$ & $16.2800^{\mathrm{a}}$ \\
\hline 5. Malaysia & 443 & $2.0257^{\mathrm{a}}$ & $0.1628^{\mathrm{a}}$ & $22.6537^{\mathrm{a}}$ & $7.7759^{\mathrm{a}}$ \\
\hline 6. Denmark & 443 & $1.6477^{\mathrm{a}}$ & 0.0731 & $6.1835^{\mathrm{a}}$ & 3.8487 \\
\hline 7. Sweden & 443 & $1.5218^{\mathrm{a}}$ & $0.2309^{\mathrm{a}}$ & $3.4737^{\mathrm{a}}$ & $9.6469^{\mathrm{a}}$ \\
\hline 8. New Zealand & 442 & $1.0431^{\mathrm{a}}$ & $0.1196^{\mathrm{c}}$ & $6.7251^{\mathrm{a}}$ & $5.3456^{\mathrm{a}}$ \\
\hline 9. Luxembourg & 442 & $0.5577^{\mathrm{b}}$ & $0.1868^{\mathrm{b}}$ & $2.3049^{\mathrm{a}}$ & $8.4203^{\mathrm{a}}$ \\
\hline 10. China & 384 & $1.3900^{\mathrm{a}}$ & $0.4953^{\mathrm{a}}$ & $274.2888^{\mathrm{a}}$ & $140.6721^{\mathrm{a}}$ \\
\hline 11. Spain & 383 & $0.9930^{\mathrm{a}}$ & $0.3332^{\mathrm{a}}$ & $16.8686^{\mathrm{a}}$ & $14.6205^{\mathrm{a}}$ \\
\hline 12. Brazil & 384 & 0.1511 & $0.1370^{\mathrm{c}}$ & $2.2740^{\mathrm{a}}$ & $6.0783^{\mathrm{a}}$ \\
\hline 13. Chile & 384 & $0.84398^{\mathrm{a}}$ & $0.3383^{\mathrm{a}}$ & $16.3984^{\mathrm{a}}$ & $15.3414^{\mathrm{a}}$ \\
\hline 14. Israel & 443 & $0.5261^{\mathrm{b}}$ & 0.1132 & 1.5603 & $4.9221^{\mathrm{a}}$ \\
\hline 15. Mexico & 384 & 0.2700 & $0.1329^{\mathrm{c}}$ & 1.1296 & $3.8483^{\mathrm{a}}$ \\
\hline 16. Switzerland & 443 & $1.2198^{\mathrm{a}}$ & $0.1606^{\mathrm{a}}$ & $8.6057^{\mathrm{a}}$ & $4.5688^{\mathrm{a}}$ \\
\hline 17. Norway & 443 & 0.2693 & $0.2322^{\mathrm{a}}$ & $3.6866^{\mathrm{a}}$ & $4.8869^{\mathrm{a}}$ \\
\hline 18. United States & 384 & $0.5970^{\mathrm{b}}$ & $0.1560^{\mathrm{b}}$ & $4.2543^{\mathrm{a}}$ & $14.8494^{\mathrm{a}}$ \\
\hline $\begin{array}{l}\text { 19. United } \\
\text { Kingdom }\end{array}$ & 442 & $0.5148^{\mathrm{a}}$ & 0.1113 & $2.3799^{\mathrm{a}}$ & $5.8072^{\mathrm{a}}$ \\
\hline 20. Hungary & 384 & $2.0821^{\mathrm{a}}$ & $0.4037^{\mathrm{a}}$ & $36.5915^{\mathrm{a}}$ & $9.6495^{\mathrm{a}}$ \\
\hline \hline
\end{tabular}

Note: critical values for $\mathrm{P}_{T}$-test: only constant $=(1 \%, 5 \%, 10 \%) 1.9900 ; 3.2600 ; 4.4800 . \mathrm{P}_{T}$-test: with constant and trend $=(1 \%, 5 \%, 10 \%) 3.9600 ; 5.6200 ; 6.8900$. Critical values for KPSS test: only constant $=(10 \%, 5 \%, 1 \%) 0.3470 ; 0.4630 ; 0.7390$. KPSS test with constant and trend $=$ $(10 \%, 5 \%, 1 \%) 0.1190 ; 0.1460 ; 0.2160$. Critical values for $\mathrm{P}_{T}$-test extracted from Elliot et. al. (1996, Table 1, p. 825). (a) Significant at 1\% probability; (b) significant at 5\% probability; (c) significant at $10 \%$ probability. The number of additional lags $(\mathrm{k})$ was obtained by the expression: $k=$ integer $\left\{4(T / 100)^{1 / 4}\right\}$ following Kwiatkowski et. al. (1992).

Source: Authors' calculations from the dataset provided by IMF (2012). 
At $5 \%$ and $10 \%$ probability, these results suggest the occurrence of fractional integration in all countries of the sample, i.e., the series, in general, cannot be considered either I (1) or I (0), since in most cases there is strong evidence against the null hypothesis in both tests. In particular, among the twenty countries, only in the case of Belgium, Brazil, Mexico and United Kingdom the stationarity (KPSS) null hypothesis is rejected at $10 \%$ probability. In all other cases, the rejection occurs at $1 \%$ and $5 \%$ probability. In all cases, the results of the $P_{T}$-test suggest rejection of the unit root hypothesis at $1 \%$ probability. These two tests above (KPSS and $\mathrm{P}_{\mathrm{T}}$-test) do not take into account possible structural changes in trend function of the series. Then, to test for persistence, we apply two additional unit root tests by considering one and two possible structural changes in the trend function at unknown time. First, we apply unit root test introduced by Perron and Rodríguez (2003) based on GLS detrending approach introduced by Elliot et al. (1996). The Table 3 presents the results for M and ADF tests choosing the date which minimizing the test statistics. ${ }^{7}$

7 Model I allows structural change in slope only and Model II allows structural change in intercept and slope. 
Table 3 - Testing for the order of integration of the real effective exchange rate - results

\begin{tabular}{|c|c|c|c|c|c|c|c|c|c|}
\hline \multirow[b]{2}{*}{ Countries } & \multicolumn{5}{|c|}{\begin{tabular}{c}
\multicolumn{2}{c}{ MADFGLS } \\
$H_{0}: Q_{t}^{i} \approx I(1), \quad i=1, \ldots, 20$.
\end{tabular}} & \multicolumn{4}{|c|}{$\begin{array}{l}\text { MZGLS }^{2} \\
I(1), i=1, \ldots, 20 .\end{array}$} \\
\hline & $N$ & Model I & $\hat{k}$ & Model II & $\hat{k}$ & Model I & $\hat{k}$ & Model II & $\hat{k}$ \\
\hline 1. Austria & 443 & $\begin{array}{c}2.8724 \\
(1992: 04)\end{array}$ & 4 & $\begin{array}{c}2.8941 \\
(1995: 05)\end{array}$ & 4 & $\begin{array}{c}2.9435 \\
(1992: 04)\end{array}$ & 4 & $\begin{array}{c}2.9667 \\
(1995: 05)\end{array}$ & 4 \\
\hline 2. Belgium & 443 & $\begin{array}{c}2.4864 \\
(2003: 03)\end{array}$ & 4 & $\begin{array}{c}2.5719 \\
(1982: 03)\end{array}$ & 4 & $\begin{array}{c}2.5638 \\
(2003: 04)\end{array}$ & 4 & $\begin{array}{c}2.6526 \\
(1982: 03)\end{array}$ & 4 \\
\hline 3. Finland & 443 & $\begin{array}{c}2.2571 \\
(1986: 11) \\
\end{array}$ & 1 & $\begin{array}{c}2.6481 \\
(1992: 09) \\
\end{array}$ & 1 & $\begin{array}{c}2.2576 \\
(1986: 11) \\
\end{array}$ & 1 & $\begin{array}{c}2.6924 \\
(1993: 01) \\
\end{array}$ & 5 \\
\hline 4. France & 384 & $\begin{array}{c}2.5266 \\
(1984: 03)\end{array}$ & 4 & $\begin{array}{c}2.5894 \\
(1984: 03)\end{array}$ & 4 & $\begin{array}{c}2.6047 \\
(1984: 03)\end{array}$ & 4 & $\begin{array}{c}2.6714 \\
(1984: 03)\end{array}$ & 4 \\
\hline 5. Malaysia & 443 & $\begin{array}{c}2.5636 \\
(2006: 02)\end{array}$ & 3 & $\begin{array}{c}2.6412 \\
(1987: 01)\end{array}$ & 3 & $\begin{array}{c}2.6216 \\
(2006: 02)\end{array}$ & 3 & $\begin{array}{c}2.7144 \\
(1987: 01)\end{array}$ & 3 \\
\hline 6. Denmark & 443 & $\begin{array}{c}3.4544 \\
(1983: 03)\end{array}$ & 4 & $\begin{array}{c}3.5623 \\
(1986: 04)\end{array}$ & 4 & $\begin{array}{c}3.6129 \\
(1983: 03)\end{array}$ & 4 & $\begin{array}{c}3.7303 \\
(1986: 04)\end{array}$ & 4 \\
\hline 7. Sv & 443 & $\begin{array}{c}3.2743 \\
(1980: 12) \\
\end{array}$ & 1 & $\begin{array}{c}3.2791 \\
(1981: 01) \\
\end{array}$ & 1 & $\begin{array}{c}3.2623 \\
(1980: 12) \\
\end{array}$ & 1 & $\begin{array}{c}3.2670 \\
(1981: 01) \\
\end{array}$ & 1 \\
\hline $\begin{array}{l}\text { 8. New } \\
\text { Zealand }\end{array}$ & 442 & $\begin{array}{c}2.9188 \\
(1986: 11)\end{array}$ & 4 & $\begin{array}{c}3.0236 \\
(1986: 04) \\
\end{array}$ & 4 & $\begin{array}{c}3.0331 \\
(1986: 11)\end{array}$ & 4 & $\begin{array}{c}3.1554 \\
(1986: 04)\end{array}$ & 4 \\
\hline 9. Luxembourg & 442 & $\begin{array}{c}2.5330 \\
(2002: 06)\end{array}$ & 0 & $\begin{array}{c}2.6082 \\
(1999: 01)\end{array}$ & 0 & $\begin{array}{c}2.4916 \\
(2002: 06)\end{array}$ & 0 & $\begin{array}{c}2.5653 \\
(1999: 01)\end{array}$ & 0 \\
\hline 10. China & 384 & $\begin{array}{c}2.87732 \\
(1989: 10)\end{array}$ & 1 & $\begin{array}{c}2.8843 \\
(1989: 10)\end{array}$ & 1 & $\begin{array}{c}2.8757 \\
(1989: 10)\end{array}$ & 1 & $\begin{array}{c}2.8928 \\
(1990: 01)\end{array}$ & 2 \\
\hline 11. Spain & 383 & $\begin{array}{c}1.9610 \\
(1984: 10)\end{array}$ & 6 & $\begin{array}{c}2.01721 \\
(1985: 04)\end{array}$ & 6 & $\begin{array}{c}1.9963 \\
(1984: 10)\end{array}$ & 6 & $\begin{array}{c}2.0626 \\
(1985: 04)\end{array}$ & 6 \\
\hline 12. Brazil & 384 & $\begin{array}{c}2.3521 \\
(2006: 05)\end{array}$ & 10 & $\begin{array}{c}2.4034 \\
(2002: 02)\end{array}$ & 10 & $\begin{array}{c}2.5645 \\
(2006: 05)\end{array}$ & 10 & $\begin{array}{c}2.6087 \\
(2002: 02)\end{array}$ & 10 \\
\hline 13. Chile & 384 & $\begin{array}{c}2.7818 \\
(1989: 03) \\
\end{array}$ & 2 & $\begin{array}{c}2.8730 \\
(1985: 07) \\
\end{array}$ & 1 & $\begin{array}{c}2.8139 \\
(1989: 03) \\
\end{array}$ & 2 & $\begin{array}{c}2.8794 \\
(1985: 07) \\
\end{array}$ & 1 \\
\hline 14. Israel & 443 & $\begin{array}{c}4.5458^{c} \\
(1996: 03) \\
\end{array}$ & 14 & $\begin{array}{c}4.5896^{\circ} \\
(1999: 08) \\
\end{array}$ & 14 & $\begin{array}{c}2.4604 \\
(1979: 12) \\
\end{array}$ & 13 & $\begin{array}{c}2.5932 \\
(1980: 01)\end{array}$ & 13 \\
\hline 15. Mexico & 384 & $\begin{array}{c}3.1984 \\
(1985: 08)\end{array}$ & 7 & $\begin{array}{c}3.2034 \\
(1988: 07)\end{array}$ & 7 & $\begin{array}{c}3.5272 \\
(1985: 08)\end{array}$ & 7 & $\begin{array}{c}3.5328 \\
(1988: 07)\end{array}$ & 7 \\
\hline $\begin{array}{l}16 . \\
\text { Switzerland }\end{array}$ & 443 & $\begin{array}{c}3.1679 \\
(1987: 08)\end{array}$ & 2 & $\begin{array}{c}3.2755 \\
(1997: 01)\end{array}$ & 2 & $\begin{array}{c}3.2261 \\
(1987: 08)\end{array}$ & 2 & $\begin{array}{c}3.3312 \\
(1997: 01)\end{array}$ & 2 \\
\hline 17. Norway & 443 & $\begin{array}{c}3.53277 \\
(1982: 11)\end{array}$ & 2 & $\begin{array}{c}3.5960 \\
(1986: 05)\end{array}$ & 2 & $\begin{array}{c}3.5671 \\
(1982: 11)\end{array}$ & 2 & $\begin{array}{c}3.6306 \\
(1986: 05)\end{array}$ & 2 \\
\hline $\begin{array}{l}\text { 18. United } \\
\text { States }\end{array}$ & 384 & $\begin{array}{c}1.85935 \\
(1986: 10) \\
\end{array}$ & 3 & $\begin{array}{c}2.0532 \\
(1984: 03) \\
\end{array}$ & 1 & $\begin{array}{c}1.8859 \\
(1986: 10) \\
\end{array}$ & 3 & $\begin{array}{c}2.0547 \\
(1984: 03) \\
\end{array}$ & 1 \\
\hline $\begin{array}{l}\text { 19. United } \\
\text { Kingdom }\end{array}$ & 442 & $\begin{array}{c}3.1217 \\
(2007: 04) \\
\end{array}$ & 1 & $\begin{array}{c}3.1551 \\
(2006: 05) \\
\end{array}$ & 1 & $\begin{array}{c}3.1152 \\
(2007: 04) \\
\end{array}$ & 1 & $\begin{array}{c}3.1462 \\
(2006: 05) \\
\end{array}$ & 1 \\
\hline 20. Hungary & 384 & $\begin{array}{c}2.2051 \\
(1989: 09)\end{array}$ & 9 & $\begin{array}{c}2.4145 \\
(2006: 11)\end{array}$ & 1 & $\begin{array}{c}2.0745 \\
(1991: 01)\end{array}$ & 9 & $\begin{array}{c}2.4194 \\
(2006: 11)\end{array}$ & 1 \\
\hline
\end{tabular}

Note: The estimated dates are between brackets. Critical values for MADF ${ }^{\mathrm{GLS}}$ : Model I $=(1 \%$, $5 \%, 10 \%)-5.89 ;-4.61 ;-4.17$ and Model II $=(1 \%, 5 \%, 10 \%)-6.41 ;-4.98 ;-4.41$. Critical values for $\mathrm{MZ}^{\mathrm{GLS}}$ : Model I $=(10 \%, 5 \%, 1 \%)-4.89 ;-4.19 ;-3.88$ and Model II $=(10 \%, 5 \%, 1 \%)-4.99$; -4.31 ; -4.07. All critical values were extracted from Perron and Rodríguez (2003, p. 10, Tab. 1). (a) Significant at $1 \%$ probability; (b) significant at $5 \%$ probability; (c) significant at $10 \%$ probability. The number of additional lags $(\mathrm{k})$ was obtained by the sequential t-test at $10 \%$ of significance because in case of applying MADF ${ }^{G L S}$ by minimizing the test statistic and for all data-dependent methods, according to the authors "the power is high for all methods to choose k" (Perron and Rodríguez, 2003, p. 13). See Perron and Rodríguez (2003, p. 12-13) for details of the procedure, results of simulations and comparisons between three different criteria.

Source: Authors' calculations from the dataset provided by IMF (2012). 
The main conclusion to extract from above results presented in Table 3 , in marked contrast with the results of $\mathrm{P}_{\mathrm{T}}$-test, and in line with the KPSS test results above (Table 2), is that we are unable to reject unit root test in all cases, except Israel at 10\% probability. As mentioned before, a step further was made by applying the Lee and Strazicich (2003) unit root test by allowing for two occasional structural changes, by considering the questions raised by Perron (1989) influential work on unit root tests. Perron (1989) argues that by ignoring structural changes in the level and/or trend, traditional unit root tests may produce misleading results.

Then, we apply more recent two-break minimum LM unit root test introduced by Lee and Strazicich (2003) in an augmented version to correct for serial correlation. Following Perron (1989), Zivot and Andrews (1992), and Lee and Strazicich (2003), we assume the "crash" model (model A) for all series of real effective exchange rates. ${ }^{8}$ In the same fashion of the authors, by starting from a maximum of $k=8$ lagged terms, the procedure looks for significance of the last augmented term, fixed in 0.10. After determining the optimal at each combination of two breaks, the breaks are determined where the LM $t$-test statistic is at a minimum. The results are shown in the Table 4 below.

The results exposed in Table 4 suggest that we are unable to reject null of nonstationarity in almost cases, except Denmark, Israel and Norway at $5 \%$ and $10 \%$ probability. Important to note that these results are in accordance with the rejection of null of KPSS test, which point out nonstationarity for almost countries of the sample.

The general conclusion which we may extract from the results exposed in Tables 2, 3, and 4 below is that there are close concordance between KPSS, MADF ${ }^{\mathrm{GLS}}$ and minimum LM unit root tests: for this sample of countries, even by allowing for multiple structural changes in the trend function, the real effective exchange rates exhibits high persistence in an environment of higher financial and commercial integration with flexible exchange rates.

8 The "crash" modelallowstwo-time changesin theintercept of the trend function both at the null and thealternativehypothesis. SeePerron (1989, p. 1364) andLeeandStrazicich(2003, p. 1083). 
Table 4 - Testing for the order of integration of the real effective exchange rate - results

\begin{tabular}{l|c|c|c|c}
\hline & \multicolumn{5}{|l}{ Two-break LM Unit Root Test } \\
& $H_{0}: Q_{t}^{i} \approx I(1), i=1, \ldots, 20$. \\
\hline \multicolumn{1}{c}{ Countries } & $N$ & $\hat{k}$ & $\hat{T}_{b}$ & t-statistic \\
\hline 1. Austria & 443 & 8 & $1981: 09 / 1996: 12$ & -2.9271 \\
\hline 2. Belgium & 443 & 3 & $1982: 02 / 1997: 12$ & -2.7552 \\
\hline 3. Finland & 443 & 5 & $1988: 02 / 1992: 08$ & -2.5722 \\
\hline 4. France & 384 & 8 & $1986: 03 / 1993: 08$ & -2.5467 \\
\hline 5. Malaysia & 443 & 3 & $1985: 09 / 1998: 04$ & -2.5873 \\
\hline 6. Denmark & 443 & 8 & $1981: 01 / 1986: 12$ & $-3.7380 c$ \\
\hline 7. Sweden & 443 & 1 & $1992: 11 / 2001: 08$ & -2.8118 \\
\hline 8. New Zealand & 442 & 8 & $1990: 09 / 1998: 04$ & -3.4383 \\
\hline 9. Luxembourg & 442 & 8 & $1980: 08 / 1993: 07$ & -2.6050 \\
\hline 10. China & 384 & 4 & $1986: 06 / 1990: 06$ & -1.1029 \\
\hline 11. Spain & 383 & 6 & $1985: 04 / 1992: 11$ & -1.9792 \\
\hline 12. Brazil & 384 & 1 & $1990: 09 / 1999: 01$ & -2.6138 \\
\hline 13. Chile & 384 & 1 & $1984: 08 / 2005: 07$ & -2.3673 \\
\hline 14. Israel & 443 & 8 & $2002: 12 / 2008: 04$ & -4.00490 \\
\hline 15. Mexico & 384 & 5 & $1995: 03 / 2000: 06$ & -3.4716 \\
\hline 16. Switzerland & 443 & 1 & $1996: 10 / 2000: 07$ & -3.0657 \\
\hline 17. Norway & 443 & 1 & $1993: 10 / 2007: 01$ & $-3.66628^{c}$ \\
\hline 18. United States & 384 & 8 & $1985: 10 / 1989: 09$ & -2.4187 \\
\hline 19. United Kingdom & 442 & 1 & $1997: 06 / 2007: 12$ & -3.1168 \\
\hline 20. Hungary & 384 & 1 & $2002: 10 / 2008: 02$ & -2.2938 \\
\hline \hline \multicolumn{5}{|c|}{}
\end{tabular}

Note: Critical values extracted from Lee and Strazicich (2003, table 2): -4.545 (1\%); -3.842 (5\%); - 3.504 (10\%); (a) significant at $1 \%$ probability; (b) significant at $5 \%$ probability; (c) significant at $10 \%$ probability.

Source: Authors' calculations from the dataset provided by IMF (2012).

This conclusion contradicts with the approach and conclusions of Baillie et al. (1996) which applied two complementary unit root tests to detect fractional behavior probably because of they do not take into account occasional changes in the level and/or trend of the series. This observation casts more cautions on the analysis of unit root test to infer fractional behavior and more attention has to be paid on periodogram and frequency analysis, since it is the main indication for fractional behavior suggested by Beran (1994). With the additional information obtained by the scatter diagrams in the Appendix (periodogram and frequency) along with the significance of fractional coefficient $d$, the conclusion reached in this study is that the sample of twenty countries provides hard evidence of fractional behavior in the real exchange rates. 
By the reasons exposed in the Introduction we move away from unit root tests and their extreme conclusions, where the series can be viewed only integrated of order 1 or 0 and adopt a more flexible alternative by estimating the fractional coefficient $d$, which is not a integer and is the only measure for long run persistence of series, since it not depend upon autoregressive coefficient of unit root tests analyzed before, which measure only its short run memory (short run persistence).

\subsection{Results for full/partitioned sample. Test for change in persistence}

The results of Table 5 below were obtained by the AGG estimator by applying the filter of the first difference. As the number of differentiated process $I(d)$ is $I(d-1)$, then the fractional coefficient was initially estimated for the first difference of the real effective exchange rate and, in the end, the fractional coefficient $d_{r}$ is obtained by summing up the unit with the coefficient $d$ estimated in first difference. Then a confidence interval of 0.95 probability using the normal distribution was calculated. The results reported above, taking into account the confidence interval of 0.95 , strongly suggest the nonstationary behavior of the real exchange rate in almost all sample countries except Denmark, Israel and United Kingdom, since the hypothesis of unit root cannot be rejected at 0.05 probability in the remaining cases.

The analysis of the results shown in Table 5 allows the following conclusions. First, of the twenty countries, only four countries (Denmark, Spain, Israel, and United Kingdom) have persistence coefficient below unity. It is important to check what it might have occurred in this scenario after the institutional reforms of the 1990s. Second, in all other cases the unit root hypothesis cannot be rejected at 0.05 probability, because the confidence interval includes the unity. Nevertheless, the results indicate the nonstationary behavior of the real exchange rate, in general, above the unity, the institutional changes introduced in the 1990s may have altered this characteristic of the series, making it stationary or increasing the long run persistence in some cases. With respect to the partitioning of the sample, it was observed that the initial period of each country does not always coincide, so, the number of observation in the first period is in general different from the second. For the partitioned sample, the first period is from January 1975 to December 1994, and the second period is from January 1995 to 
December 2011. Summing up, we have 20 countries with monthly data from 1975 to November 2011. It is important to note, however, that trade and financial liberalization has intensified since the 1990s, as indicated by the studies by Lane and Milesi-Ferretti (2003, 2006), Santos-Paulino (2002) and Kose et al. (2006) applying the measure of financial integration between countries.

Table 5 - Estimates for the full sample - ARFIMA $\left(0, d_{r}, 0\right)$

\begin{tabular}{|c|c|c|}
\hline Países & $\hat{d}_{r}$ & IC 95\% \\
\hline 1. Austria & $\begin{array}{c}0.6277^{\mathrm{b}} \\
(2.0177)\end{array}$ & $0.0179 ; 1.2375$ \\
\hline 2. Belgium & $\begin{array}{c}0.6095^{\mathrm{b}} \\
(1.95918)\end{array}$ & $-0.0003 ; 1.2193$ \\
\hline 3. Finland & $\begin{array}{l}0.8705^{\circ} \\
(2.7981) \\
\end{array}$ & $0.2607 ; 1.4803$ \\
\hline 4. France & $\begin{array}{c}0.8606^{\mathrm{b}} \\
(2.5621)\end{array}$ & $0.2022 ; 1.5190$ \\
\hline 5. Malaysia & $\begin{array}{l}0.97877^{\circ} \\
(3.1459) \\
\end{array}$ & $0.3689 ; 1.5885$ \\
\hline 6. Denmark & $\begin{array}{c}-0.0909 \\
(-0.2922)\end{array}$ & $-0.7007 ; 0.5189$ \\
\hline 7. Sweden & $\begin{array}{l}0.5800^{\mathrm{a}} \\
(1.8643)\end{array}$ & $-0.0298 ; 1.1898$ \\
\hline 8. New Zealand & $\begin{array}{l}0.8787 c \\
(2.7213)\end{array}$ & 0.24581 .5116 \\
\hline 9. Luxembourg & $\begin{array}{l}0.8931^{c} \\
(2.7659) \\
\end{array}$ & $0.2602 ; 1.5260$ \\
\hline 10. China & $\begin{array}{c}1.5479 c \\
(4.6082)\end{array}$ & $0.8895 ; 2.2063$ \\
\hline 11. Spain & $\begin{array}{c}0.2558 \\
(0.7615)\end{array}$ & $-0.4026 ; 0.9142$ \\
\hline 12. Brazil & $\begin{array}{c}0.9353^{c} \\
(2.7845) \\
\end{array}$ & $0.2769 ; 1.5937$ \\
\hline 13. Chile & $\begin{array}{c}0.9474 c \\
(2.82048) \\
\end{array}$ & $0.2890 ; 1.6058$ \\
\hline 14. Israel & $\begin{array}{c}0.3533 \\
(1.1356)\end{array}$ & $-0.2565 ; 0.9631$ \\
\hline 15. Mexico & $\begin{array}{c}0.5020 \\
(1.4945)\end{array}$ & $-0.1564 ; 1.1604$ \\
\hline 16. Switzerland & $\begin{array}{l}0.7414^{b} \\
(2.3832)\end{array}$ & $0.1316 ; 1.3512$ \\
\hline 17. Norway & $\begin{array}{c}0.8382^{c} \\
(2.6943)\end{array}$ & $0.2284 ; 1.4480$ \\
\hline 18. United States & $\begin{array}{c}0.6725^{\mathrm{b}} \\
(2.0021)\end{array}$ & $0.0141 ; 1.3309$ \\
\hline 19. United Kingdom & $\begin{array}{c}0.3045 \\
(0.9430) \\
\end{array}$ & $-0.3284 ; 0.9374$ \\
\hline 20. Hungary & $\begin{array}{l}1.0760^{c} \\
(3.2033)\end{array}$ & $0.4176 ; 1.7344$ \\
\hline
\end{tabular}

Note: the sample period of each country is the same as described in table 1. T statistics calculated between brackets. Critical values (probability): 1.66 (0.10); $1.96(0.05) ; 2.58$ (0.001). (a) Significant at $1 \%$ probability; (b) significant at 5\% probability; (c) significant at 10\% probability. Source: Authors' calculations from the dataset provided by IMF (2012). 
Analyzing the results shown in Table 6 below, two important conclusions can be drawn.

First off all, some countries like Malaysia, Sweden and Norway have experienced a remarkable decrease in long run persistence. And on the other hand, some countries (Austria, Mexico, Switzerland, Luxembourg, United Kingdom and Denmark) showed a substantial increase in persistence, becoming more unstable after the institutional reforms of that period.

Table 6 - Estimates for the partitioned sample - 1975:01-1994:12; 1995:012011:11

\begin{tabular}{l|l|l|l|l|l}
\hline Country & $n_{1}$ & $n_{2}$ & $d_{r 1}$ & $d_{r 2^{2}}$ & Change \\
\hline \hline 1. Austria & 239 & 202 & $0.3406(0.8395)$ & $1.3398^{\mathrm{a}}(3.1180)$ & $\Uparrow$ \\
\hline 2. Belgium & 239 & 202 & $1.3388^{\mathrm{a}}(3.2999)$ & $1.2846^{\mathrm{a}}(2.9895)$ & $\Downarrow$ \\
\hline 3. Finland & 239 & 202 & $1.5963^{\mathrm{a}}(3.9347)$ & $1.1306^{\mathrm{a}}(2.6311)$ & $\Downarrow$ \\
\hline 4. France & 180 & 202 & $1.3580^{\mathrm{a}}(2.9677)$ & $1.1441^{\mathrm{a}}(2.6626)$ & $\Downarrow$ \\
\hline 5. Malaysia & 239 & 202 & $1.3730^{\mathrm{a}}(3.3843)$ & $0.8450^{\mathrm{b}}(1.9665)$ & $\Downarrow$ \\
\hline 6. Denmark & 239 & 202 & $0.5709(1.4072)$ & $1.2981^{\mathrm{a}}(3.0209)$ & $\Uparrow$ \\
\hline 7. Sweden & 239 & 202 & $0.5406(1.3325)$ & $0.3508(0.8164)$ & $\Downarrow$ \\
\hline 8. New Zealand & 238 & 202 & $1.0371^{\mathrm{b}}(2.5563)$ & $0.9048^{\mathrm{b}}(2.1057)$ & $\Downarrow$ \\
\hline 9. Luxembourg & 238 & 202 & $0.94277^{\mathrm{b}}(2.3236)$ & $1.5342^{\mathrm{a}}(3.5704)$ & $\Uparrow$ \\
\hline 10. China & 180 & 202 & $0.9216^{\mathrm{b}}(2.0140)$ & $1.3335^{\mathrm{a}}(3.1033)$ & $\Uparrow$ \\
\hline 11. Spain & 179 & 202 & $1.6072^{\mathrm{a}}(3.5122)$ & $1.3435^{\mathrm{a}}(3.1266)$ & $\Downarrow$ \\
\hline 12. Brazil & 180 & 202 & $1.0766^{\mathrm{b}}(2.3527)$ & $1.3063^{\mathrm{a}}(3.0400)$ & $\Uparrow$ \\
\hline 13. Chile & 180 & 202 & $1.0983^{\mathrm{b}}(2.4001)$ & $0.9065^{\mathrm{b}}(2.1096)$ & $\Downarrow$ \\
\hline 14. Israel & 239 & 202 & $0.4411(1.0873)$ & $0.9949^{\mathrm{b}}(2.3153)$ & $\Uparrow$ \\
\hline 15. Mexico & 180 & 202 & $0.7071(1.5452)$ & $1.1628^{\mathrm{a}}(2.7061)$ & $\Uparrow$ \\
\hline 16. Switzerland & 239 & 202 & $0.1889(0.4656)$ & $1.4501^{\mathrm{a}}(3.3747)$ & $\Uparrow$ \\
\hline 17. Norway & 239 & 202 & $1.2990^{\mathrm{a}}(3.2019)$ & $0.0430(0.1001)$ & $\Downarrow$ \\
\hline 18. United States & 180 & 202 & $1.6514^{\mathrm{a}}(3.6088)$ & $1.3325^{\mathrm{a}}(3.1010)$ & $\Downarrow$ \\
\hline 19. United Kingdom & 238 & 202 & $0.5189(1.2790)$ & $1.2677^{\mathrm{a}}(2.9502)$ & $\Uparrow$ \\
\hline 20. Hungary & 180 & 202 & $1.9432^{\mathrm{a}}(4.2465)$ & $1.1338^{\mathrm{a}}(2.6386)$ & $\Downarrow$ \\
\hline \hline
\end{tabular}

Note: $\mathrm{t}$ statistics between brackets. Critical values (probability): 1.66 (0.10); 1.96 (0.05); 2.58 (0.001). (a), (b), (c) statistically significant at $0.01 ; 0.05$; and 0.10 of probability, respectively.

Source: Authors' calculations from the dataset provided by IMF (2012). 
Importantly, these last two countries (United Kingdom and Denmark) had low persistence before the mid-1990s. Excepting the case of Malaysia, Sweden, Chile and Israel, there is no evidence of stationarity for the real effective exchange rate in any of the other countries in the sample, since the fractional coefficient is not located below the unity. Furthermore, in nine cases there was a substantial increase in the persistence of the real exchange rate and not a decrease, as previously pointed out by some authors (see, for example, Okimoto and Shimotsu, 2010). In other cases, the observed decrease in persistence was not enough to make the exchange rate stationary, which coefficient remained substantially above unity after the institutional reforms of the mid-1990s.

Indeed, this result is consistent with Lee and Strazicich (2003) test for high persistence with corroborate with the conclusion that trade and financial integration may help to explain the advent of more instable economies in the last decades when we consider the long run persistence of its real exchange rate. The increased volatility of exchange rate may have to contribute to cross and maintain persistence higher than unity (Rogoff, 1996; Engel, 2000). Another aspect that can be considered a potential candidate to explain these behaviors is the 'edge' between international prices and the existence of non-tariff barriers to trade. All these aspects may have contributed to high long run persistence and more instable competitiveness of countries. The last issue to be addressed from the aforementioned results is whether this change in the persistence of real exchange rate can be systematically generalized to be considered for a large number of countries, as the Table would suggest, or whether no significant change occurred in persistence even with the institutional changes introduced in the mid-1990s.

To test whether the changes in institutional conditions of the countries have significantly altered the persistence of the real exchange rate of the countries, in general, nonparametric Wilcoxon test and the traditional means test for paired samples (parametric) were used. The advantage of the Wilcoxon test, in relation to its parametric alternative, is that it does not require the assumption of normality or equal variances and the power of the test is high even for small samples. 
The last column of Table 6 point out the directions of variation in fractional coefficient $d$, but these observations does not permit to infer general and systematic conclusions. Visually it is difficult to know the final balance from the last column of Table 6, if there was an increase or systematic decline in the persistence of the exchange rate on aggregate countries. Therefore, this question can be answered with a test for change in persistence, in which the hypothesis of maintenance of persistence is tested against the hypothesis of decrease in persistence.

The Wilcoxon test requires assigning scores for each fractional difference between the two coefficients obtained under different conditions (before and after 1995). These differences are ranked and the sum of the positions results in a statistical $T$, which value depends on the size of paired samples $(n=20)$. When the sample size is greater than 15 , it is shown that the $t$ statistic is normally distributed with mean,

$$
\mu_{T}=\frac{n(n+1)}{4}
$$

And variance given by,

$$
\sigma_{T}^{2}=\frac{n(n+1)(2 n+1)}{24}
$$

Therefore, for a sample of twenty countries, the Wilcoxon statistic is normally distributed with mean zero and variance given by,

$$
z=\frac{T-\mu_{T}}{\sigma_{T}}=\frac{T-n(n+1) / 4}{\sqrt{n(n+1)(2 n+1) / 24}}
$$

The results for the Wilcoxon test and its parametric version are summarized in Table 7 below. The results of the $t$ test for large samples (with the assumption of normality) are also shown for comparison purposes only. 
Table 7 - Test for change in persistence - Results

\begin{tabular}{|l|l|l|}
\hline \multicolumn{2}{|l|}{ Parametric $t$ test } & Wilcoxon test \\
\hline Calculated statistics & $t=0.5469$ & $T=121$ \\
\hline P-value & 0.7046 & 0.7271 \\
\hline
\end{tabular}

Source: Authors' calculations from the dataset provided by IMF (2012).

The test results presented in Table 7 above allow us to conclude that the null hypothesis of equal persistence (maintenance of persistence), before and after the institutional changes cannot be rejected. In other words, there is no evidence that the institutional changes occurred in the various economies in the mid-1990s rendered the real exchange rate significantly less persistent or stationary. We conclude that, when the evolution of competitiveness among the countries is properly measured taking into account the weight of trade between economies, there is no evidence that trade integration and financial liberalization have reduced the persistence of the real exchange rate towards parity.

Rather, the results suggest at least that the nonstationarity of the real exchange rate is still a predominant feature in most countries and the Balassa-Samuelson effect and the volatility of the nominal exchange rate deserve more attention from economists as pointed out by Engel (2000) and Rogoff (1996).

\subsection{Estimation of the fractional coefficient with moving window}

In this section, we discuss the results of the 15-year moving window procedure for the fractional coefficient, in which each coefficient was estimated with 180 observations. This procedure was adopted for comparison with the results found by Okimoto and Shimotsu (2010) which made the same procedure for the same time window. This choice does not affect the consistence of the AGG estimator, since it shown good performance in small samples $(n=128$ or greater) (Andrews and Guggenberger, 2003, p. 698).

Although the sample of countries is not exactly the same, this procedure can offer a more precise idea of the path of persistence in recent decades and history of institutional reforms in each country 
which affects the long run persistence of exchange rate. It is important to note that the measure of real exchange rate used takes into account the weight of trade between countries. Therefore, as the financial and trade integration in the mid-1990s was accentuating, the persistence of competitiveness may also have gone through important changes that are easily visualized with this procedure.

The estimation started in the period 1980:02-1994:12 with increase of 12 months in each estimation, so that the second coefficient was estimated in the fixed sample in 1981:02-1995:12, and so on. The end of the estimations was in the period 1996:02-2010:12, generating 17 fractional coefficients at the end, which were ordered in time (figures $2 \mathrm{a}$ and $2 \mathrm{~b}$ in the Appendix). The initial period for all countries in the sample was determined by the availability of data for Spain, which data were available only from 1980:01 to the level of the variable. The estimation of each fractional coefficient followed the same procedure described in the Methodology.

Analyzing figures $2 \mathrm{a}$ and $2 \mathrm{~b}$, we obtain three important conclusions: the persistence of the real exchange rate has undergone major changes over the years 1980 to 2000, however, most of the time it remained in the region above the unity (nonstationary), suggesting the rejection of the hypothesis of purchasing power parity. In the case of Brazil, for example, whose openness and current account liberalization occurred in early 1990, we can see a marked decline in persistence since then, but not sufficient to make real exchange rate stationary. After all, in 2000 decade this country recovery their instability (higher coefficient $d$ ), and maintain it above the unity since then.

Second, only the cases of Malaysia, Sweden, Switzerland, Norway and Hungary show a sustainable downward trend in the persistence in some periods. The only country of the sample in which a decrease in the persistence can be unequivocally detected, also taking into account the results by Okimoto and Shimotsu (2010, Figure 2, p. 405), is Switzerland.

As for Austria, France, New Zealand, Luxembourg, Israel, Mexico and United Kingdom there has been a notable increase in the long run persistence of the real exchange rate after institutional changes of mid-1990s. The case of Austria has the highest contrast with the 
results by Okimoto and Shimotsu (2010, Figure 2, p. 405). In the other sample countries (8 countries), the results suggest that persistence has not been subjected to significant changes over the decades. With this procedure, it can be more clearly seen that progressive trade and financial integration of the mid-1990s did not significantly reduce the persistence of the real exchange rate, as the results of Tables 5 and 6 suggest.

\section{Conclusions}

Having regard to the factors that contribute to stabilizing the economies and their possible impact on other countries through increased financial and trade integration, the aim of the study was to verify whether the stabilizing influences are also being transmitted to the level of competitiveness of countries, offsetting the volatility of the nominal exchange rate, thus favoring the hypothesis of purchasing power parity.

The institutional changes implemented in several countries in the 1990s could have rendered the stationary real exchange rate with low long run persistence. The methodology consisted in employing a fractional approach, alternative to the unit root tests, through the AGG estimator which showed better performance compared with other semiparametric estimators (Whittle and GPH) in simulations to measure the efficiency and bias of the estimator.

The long run persistence of the real exchange rate was estimated for two historical periods: before and after the trade openness and financial liberalization of the mid-1990s. The central hypothesis was that the persistence coefficient $d$ was statistically lower in most countries after the financial and trade integration since the 1990s by the action of the stabilizing factors, which would offset the volatility of the nominal exchange rate. In general, the results do not corroborate the findings by Okimoto and Shimotsu (2010). Indeed, for a number of countries there was an increase in the persistence of the real exchange rate. 
The hypothesis of equal persistence before and after the institutional changes of the 1990s cannot be rejected at 0.05 probability. Therefore, there is no evidence of a statistically significant change in the persistence of the real exchange rate. One limitation of the work is the fact that it does not analyze in detail the factors that may have contributed to the increase or maintenance of persistence of the real exchange rate between the countries, in the analyzed period. This task is beyond the scope of this study.

\section{References}

ANDREWS, D. W. K.; GUGGENBERGER, P. “A bias-reduced log-periodogram regression estimator for the long memory parameter", Econometrica, vol. 71(2): 675-712, 2003.

AGIAKLOGLOU, C.; NEWBOLD, P.; WOHAR, M. "Bias in an estimator of the fractional difference parameter”, Journal of Time Series Analysis, vol. 14, pp. 235-246, 1993.

ARSHANAPALLI, B.; DOUKAS, J.; LANG, L. H. P. "Pre and post-October 1987 stock market linkages between U.S. and Asian markets”, Pacific-Basin Financial Journal, vol. 3, pp. 57-73, 1995.

BAILlIE, R., CHUNG, C.-F.; TIESLAU, M. A. "Analyzing inflation by the fractionally integrated arfima-garch model”, Journal of Applied Econometrics, Vol. 11, pp. 23-40, 1996.

BALASSA, B. “The Purchasing Power Parity Doctrine: A Reappraisal”, Journal of Political Economy, 72, 584-596, 1964.

BANERJEE, A.; LUMSDAINE, R. L.; STOCK, J. H. "Recursive and Sequential Tests of the Unit-Root and Trend-Break Hypotheses: Theory and International Evidence", Journal of Business \& Economic Statistics, vol. 10(3), pp. 271-287, 1992.

BERAN, J. Statistics for long memory processes, New York: Chapman and Hall, 1994.

CLINE, W.R., WILLIMANSON, J. "Estimates of Fundamental Equilibrium Exchange Rates", Policy Brief, Peterson Institute for International Economics, Number PB10-15, 2011.

CRYER, J.D., CHAN, K.S. Time Series Analysis. New York: Springer, 2008.

DIVINO, J. A., TELES, V. K., ANDRADE, J. P. “On the purchasing power parity for Latin-American countries", Journal of Applied Economics, vol. 12(1), pp. 33-54, 2009.

EICHENGREEN, B.; ROSE, A.; WYPLOSZ, C. "Contagious Currency Crises”, NBER Working Paper 5681, National Bureau Economic Research, 1996.

ELLIOTT G.; ROTHENBERG, T. J.; STOCK, J. H., "Efficient tests for autoregressive unit root", Econometrica, vol. 64(4), pp. 813-836, 1996.

ENGEL, C. "Lon-run PPP may not hold after all”, Journal of International Economics, vol. 57, pp. 243-273, 2000.

FIGUEIREDO, E. A.; MARQUES, A. M. "Inflação inercial como um processo de longa memória: análise a partir de um modelo arfima-figarch”, Estudos Econômicos, vol. 39(2), pp. 437-458, 2009.

FOX, R.; TAQQU, M. S. "Large-sample properties of parameter estimates for strongly dependent stationary Gaussian time series", Annals of Statistics, vol. 14(2), pp. 517-532, 1986. 
FRANCO, G. H. B. "A inserção externa e o desenvolvimento", Revista de Economia Politica, vol. 18(3/71): 121-147, 1998.

GEWEKE, J.; PORTER-HUDAK, S. "The estimation and application of long memory time series models", Journal of Time Series Analysis, vol. 4(4), pp. 221-238, 1983.

HELMERS, F. "The real exchange rate", In: DORNBUSCH, R., HELMERS, F. (eds.). The Open Economy: tools for policymakers in developing countries, Oxford: Oxford University Press, 10-33, 1991.

HOSKING, J. "Fractional differencing”, Biometrika, vol. 68(1), pp. 165-176, 1981.

INTERNATIONAL MONETARY FUND. International Financial Statistics. CD-ROM, 2012.

JOYCE, J. P.; KAMAS, L. "Real and nominal determinants of real exchange rates in Latin America: short-run dynamics and long-run equilibrium", Journal of Development Studies, vol. 39(6): 155-182, 2003.

KIM, S.; LIMA, L. R. "Local persistence and PPP the hypothesis", Journal of International Money and Finance, vol. 29, pp. 555-569, 2010.

KOSE, M. A.; PRASAD, ROGOFF, K.; WEI, S.-J. "Financial globalization: a reappraisal”, IMF Working Paper, WP/06/189, International Monetary Fund, 2006.

KUMAR, M. S.; OKIMOTO, T. "Dynamics of Persistence in International Inflation Rates", Journal of Money, Credit and Banking, vol. 39(6): 1457-1479, 2007.

KWIATKOWSKI, D.; PHILLIPS, P. C. B; SCHMIDT, SHIN, Y. "Testing the null hypothesis against the alternative of a unit root", Journal of Econometrics, vol. 54, pp. 159-178, 1992.

LANE, P., MILESI-FERRETTI, G., "The external wealth of nations mark II: revised and extended estimates of foreign assets and liabilities, 1970-2004", IMF Working Paper 06/69, International Monetary Fund, 2006.

LEE, J.; STRAZICICH, M. C. "Minimum Lagrange Multiplier Unit Root Test with Two Structural Breaks", Review of Economics and Statistics, vol. 85(4): 1082-1089, 2003.

LOTHIAN, J., TAYLOR, M., "Real exchange rate behavior: the problem of power and sample size", Journal of International Money and Finance, vol. 16(6), pp. 945-54, 1997.

LUMSDAINE, R.; PAPELL, D. "Multiple trend breaks and the Unit-root Hypothesis", Review of Economics and Statistics, 79(2): 212-218, 1997.

OBSTFELD, M., ROGOFF, K. Foundations of International Macroeconomics, Cambridge: MIT, 1996.

OKIMOTO, T.; SHIMOTSU, K. "Decline in the persistence of real exchange rates, but not sufficient for purchasing power parity", Journal of The Japanese and International Economies, vol. 24, pp. 395-411, 2010.

PERRON, P. "The Great Crash, the Oil Price Shock, and the Unit Root Hypothesis", Econometrica, 57(6): 1361-1401, 1989.

PERRON, P.; RODRÍGUEZ, G. "GLS detrending, efficient unit root tests and structural change", Journal of Econometrics, vol. 115, pp. 1-27, 2003.

PHILLIPS, P.C.B.; PERRON, P. "Testing for a unit root in time series regression", Biometrika, 75(2), 335-346, 1988.

PIVETTA, F.; REIS, R. "The persistence of inflation in the United States", Journal of Economic Dynamics and Control, vol. 31, pp. 1326-1358, 2007.

RAJAN, R. S., SEN, R.; SIREGAR, R., "Hong Kong, Singapore and the East Asian Crisis: How Important Were Trade Spillovers?" (August). CIES Discussion Paper No. 0042; HKIMR Working Paper No. 14/2002, 2002. Disponível em: http://ssrn.com/abstract=253319 ou http://dx.doi. org/10.2139/ssrn.253319

ROBINSON, P. M. "Log-periodogram regression of time series with long range dependence", Annals of Statistics, vol. 23(3), pp. 1048-1072, 1995. 
ROGOFF, K. "The Purchasing Power Parity Puzzle", Journal of Economic Literature, vol. 34(2): 647-668, 1996.

SANTOS-PAULINO, A. U. "Trade liberalization and export performance in selected developing countries”, Journal of Development Studies, vol. 39(1): 140-164, 2002.

SARNO, L., TAYLOR, M. "Purchasing Power Parity and the Real Exchange Rate", IMF Staff Papers, 49(1), 65-105, 2002.

SENSIER, M.; van DIJK, D. "Testing for volatility changes in US macroeconomic time series”, Review of Economics and Statistics, vol. 86(3), pp. 833-839, 2004.

SIEGEL, S.; CASTELLAN, N. J. Nonparametric Statistics for the Behavioral Sciences, New York: McGraw-Hill, 1988.

SILVA, C. G.; VIEIRA, F. V. "Persistência inflacionária regional brasileira: uma aplicação dos modelos arfima”, Economia Aplicada, vol. 17(1): 115-134, 2013.

SOWELL, F. "Modeling long-run behavior with the fractional ARIMA model", Journal of Monetary Economics, vol. 29, pp. 277-302, 1992.

SUMMERS, R.; HESTON, A. "Pen World Tables (mark 5): an expanded set of international comparisons, 1950-88”, Quarterly Journal of Economics, vol. 106: 327-368, 1991.

TAYLOR, A. "A Century of Purchasing-Power Parity", Review of Economics and Statistics, 84(1), 139-150, 2002.

TAYLOR, A., TAYLOR, M. “The Purchasing Power Parity Debate”, Journal of Economic Perspectives, 18(4), 135-158, 2004.

THE R DEVELOPMENT CORE TEAM R: A language and environment for statistical computing. R Foundation for Statistical Computing, Vienna, Austria, 2013. http://www.r-project.org

ZIVOT, E.; ANDREWS, D. W. K. "Further evidence on the Great Crash, the Oil-Price Shock and the Unit Root Hypothesis", Journal of Business and Economics Statistics, 10(3): 251-270, 1992. 


\section{Appendix}
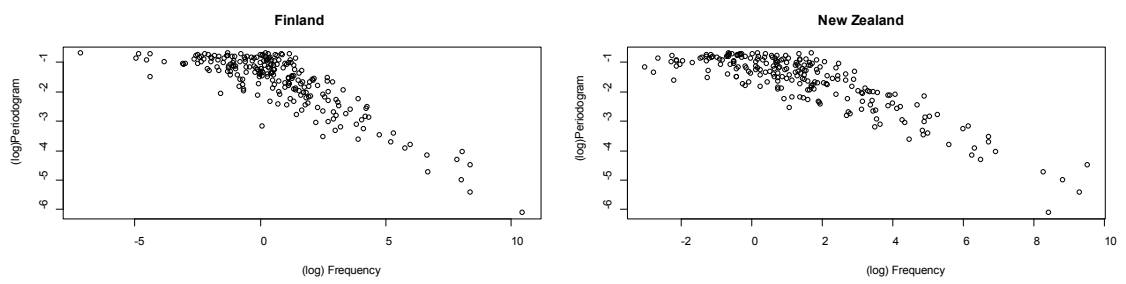

Luxembourg
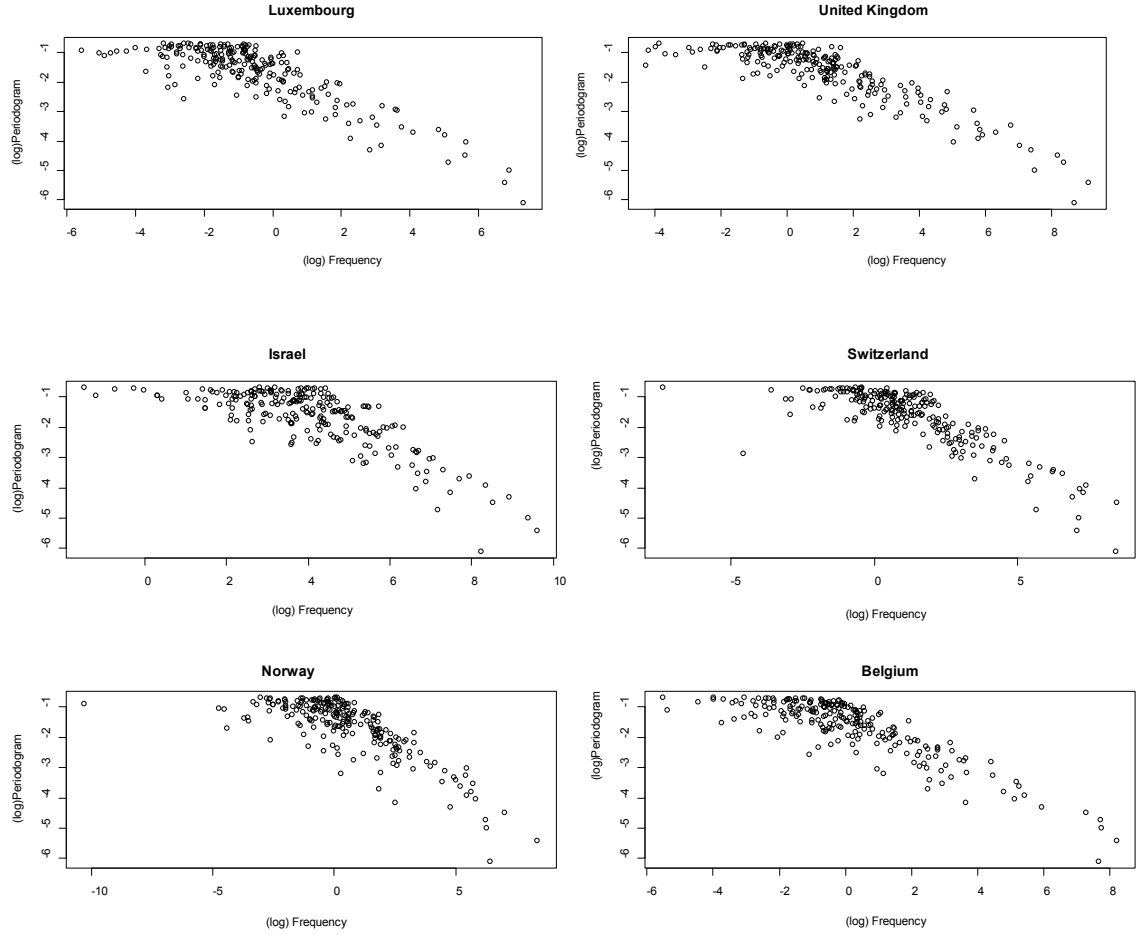

Figure la: Scatter plot (log-log scale) frequency and periodogram. 

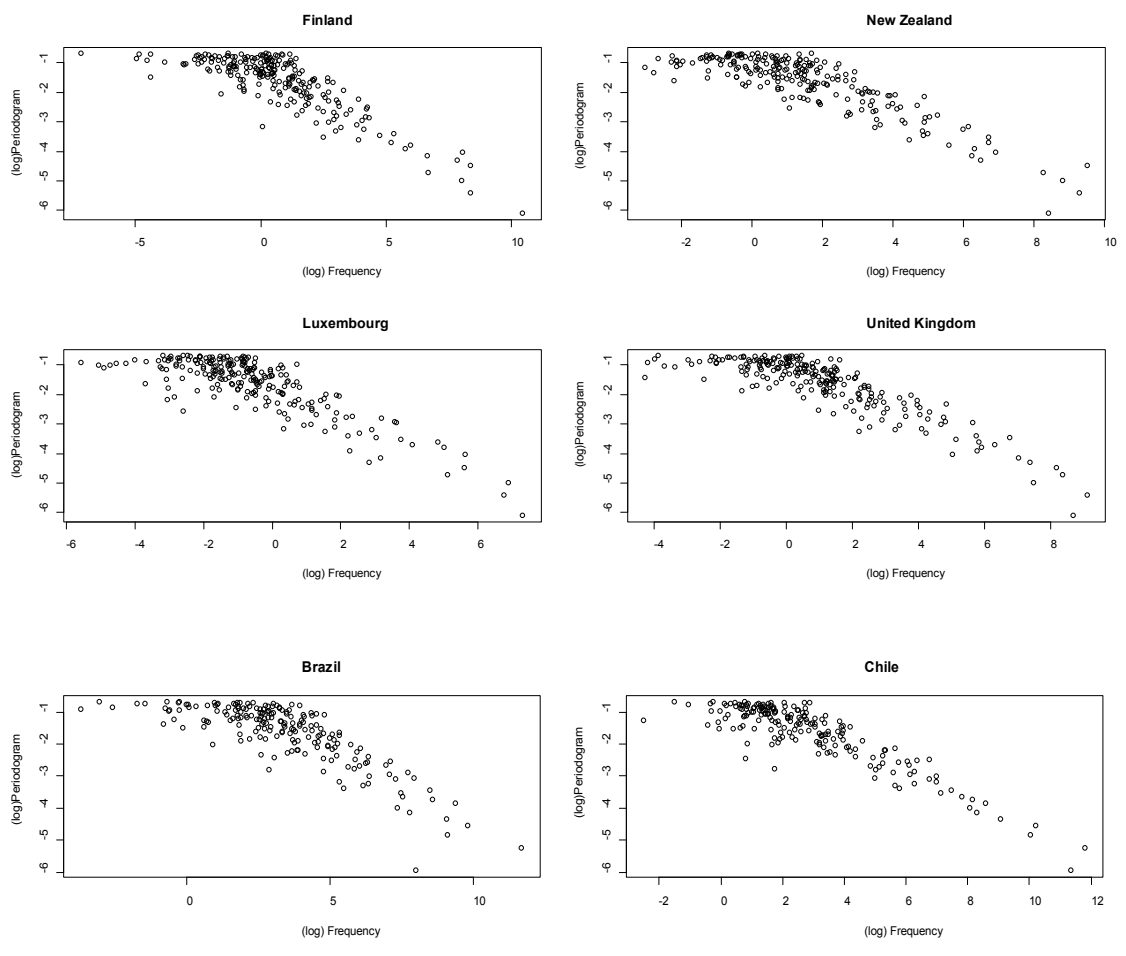

China
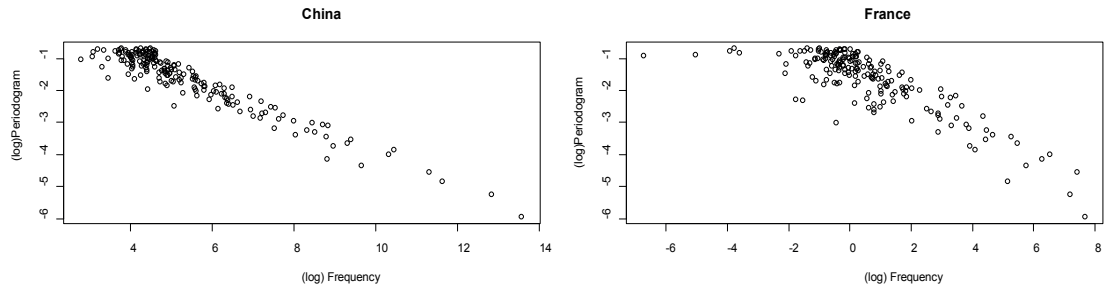

Figure 1b: Scatter plot (log-log scale) frequency and periodogram. 

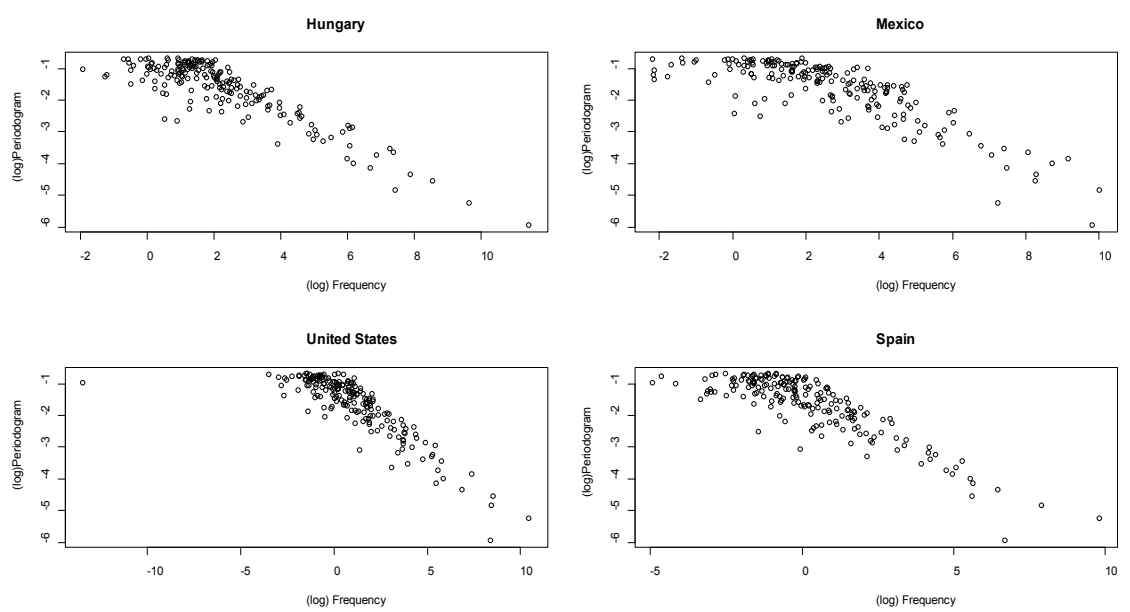

Figure 1c: Scatter plot (log-log scale) frequency and periodogram. 

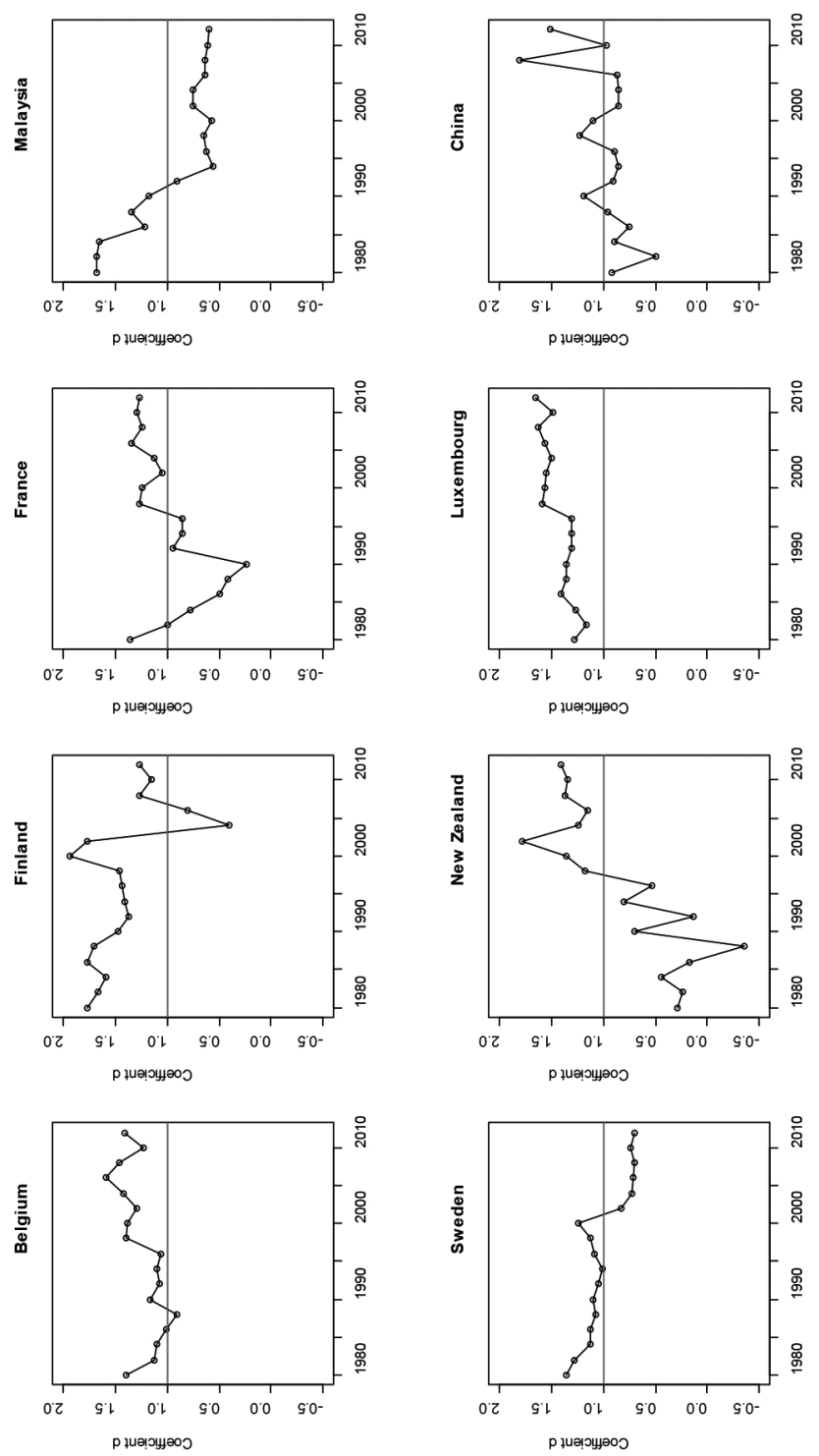

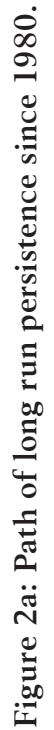
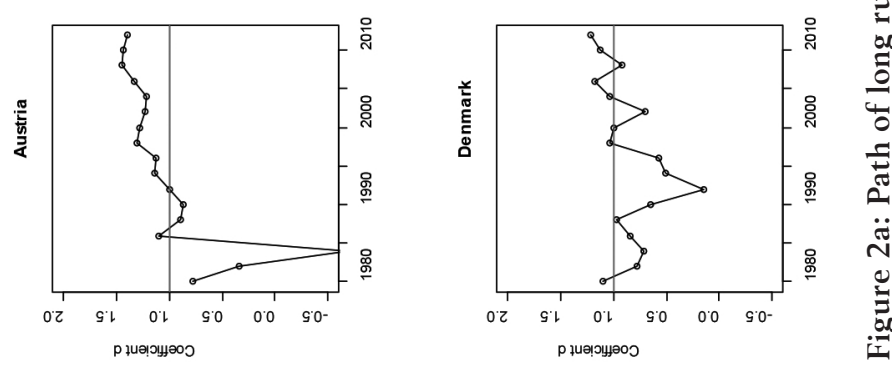

Estud. Econ., São Paulo, vol. 45, n.4, p. 821-857, out.-dez. 2015 

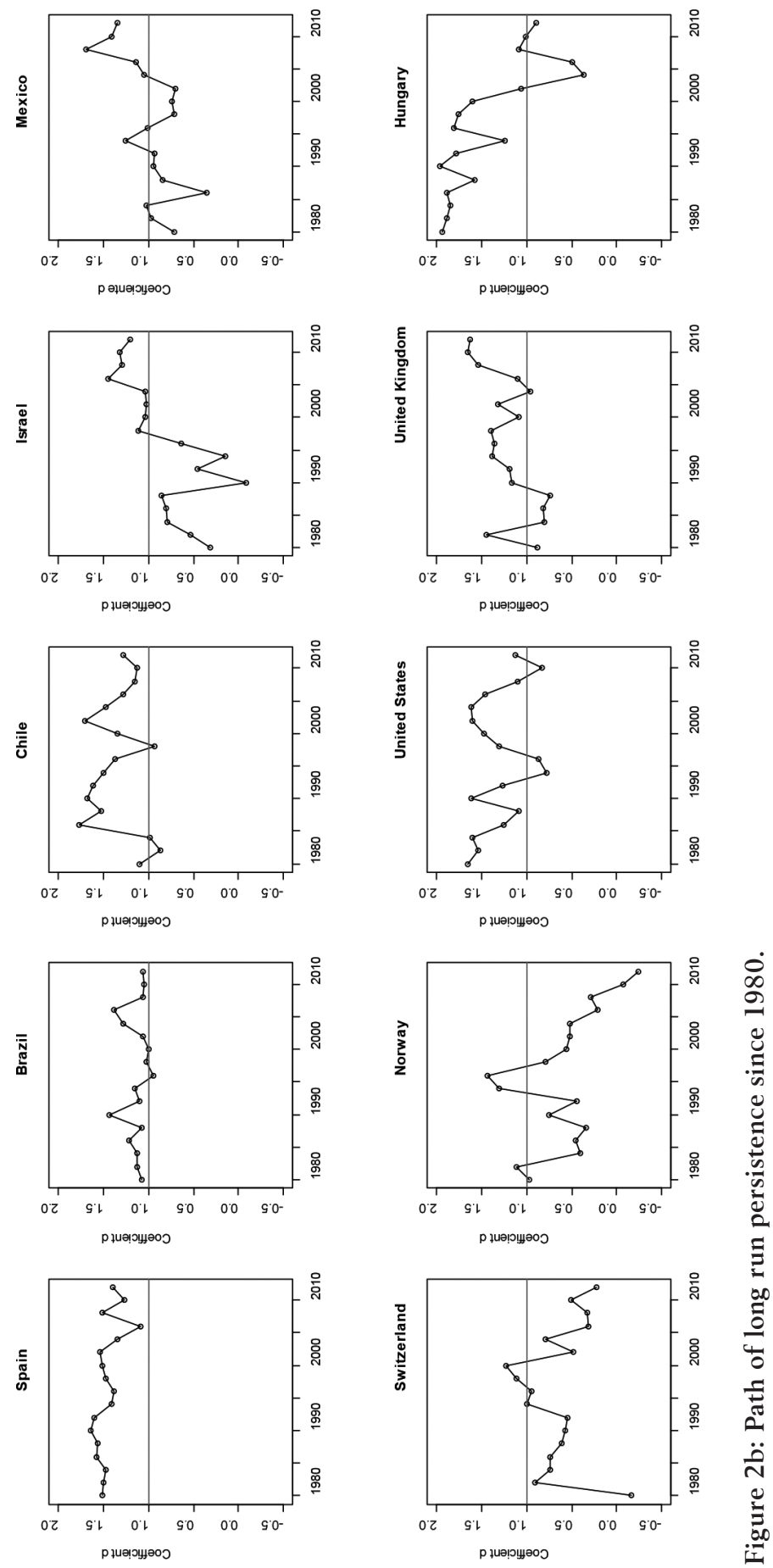